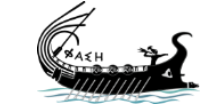

journal.phaselis.org
PHAS LLIS

Issue IV (2018)
Disiplinlerarası Akdeniz Araştırmaları Dergisi

Journal of Interdisciplinary Mediterranean Studies

\title{
Tymno-Karians or Transformers of the Bozburun Peninsula during the Hellenistic Period? Retrospective Reflections of a Demos on the Karian Cultural Heritage
}

\author{
Kar-Tymnoslular ya da Bozburun Yarımadası'nın Hellenistik \\ Dönemdeki Dönüştürücüleri? Bir Halkın Karya Kültürel Miras \\ Üzerindeki Geçmişe Dönük Yansımaları
}

\section{E. Deniz OĞUZ-KIRCA}

The entire contents of this journal, Phaselis: Journal of Interdisciplinary Mediterranean Studies, is open to users and it is an 'open access' journal. Users are able to read the full texts, to download, to copy, print and distribute without obtaining the permission of the editor and author(s). However, all references to the articles published in the e-journal Phaselis are to indicate through reference the source of the citation from this journal.

Phaselis: Journal of Interdisciplinary Mediterranean Studies is a peer-reviewed journal and the articles which have had their peer reviewing process completed will be published on the web-site (journal.phaselis.org) in the year of the journal's issue (e.g. Issue III: JanuaryDecember 2017). At the end of December 2017 the year's issue is completed and Issue IV: January-December 2018 will begin.

Responsibility for the articles published in this journal remains with the authors.

Citation E. D. Oğuz-Kırca, "Tymno-Karians or Transformers of the Bozburun Peninsula during the Hellenistic Period? Retrospective Reflections of a Demos on the Karian Cultural Heritage". Phaselis IV (2018) 259-294. http://dx.doi.org/10.18367/Pha.18017

Received Date: 31.05.2018 | Acceptance Date: 18.09.2018

Online Publication Date: 25.10.2018

Editing Phaselis Research Project

www.phaselis.org 


\title{
Tymno-Karians or Transformer of the Bozburun Peninsula during the Hellenistic Period? Retrospective Reflections of a Demos on the Karian Cultural Heritage
}

\author{
Kar-Tymnoslular ya da Bozburun Yarımadası'nın Hellenistik Dönemdeki Dönüştürücüleri? \\ Bir Halkın Karya Kültürel Miras Üzerindeki Geçmişe Dönük Yansımaları
}

\author{
E. Deniz OĞUZ-KIRCA*
}

\begin{abstract}
This paper examines the local imprints within which Karian patterns might have been embedded in the centrum and territorium of ancient Tymnos, in modern Bozburun Peninsula. The primary goal of the paper is to explore the way in which the Tymnian community and the associated ethnos, could have expressed themselves via multiple means, in the course of Hellenization and transition process of the Peninsula into the patronage of the Island of Rhodes, as back as the late Classical period. It presents, as a rough estimate, a spatial autopsy and a sketchy vectoral habitat of the epigraphical material (mostly of the ${ }{ }^{\text {nd }}$ century B.C- $\left.\right|^{\text {st }}$ century A.D) regardless of in situ/ non in situ condition, over a $2.5 \mathrm{~km}$ radius of the physical domain, by referring to the published corpus epigraphicum. It then explicates quite a general socio-cultural pattern of the oldest inhabitants, in light of the assimilated deities of the town as reflected through the cultic system of the Karians and ancient Peninsulars and, in a variety of contexts. As the discussions lead and the results display, scant but challenging indicators can suggest a Tymniannes, with a sense of autonomy, preferably achieved through the divine epithets, perhaps the political posts and minorities (if not the elite

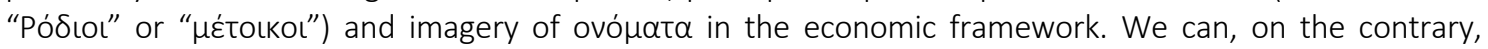
neither articulate the loci to which the Tymnian identity or the respective onomastics are linkable with precision nor a fully showcased indigenousness at a single event.
\end{abstract}

Keywords: Karia, Peraia, Tymnos, Lex Sacra, Hera and Zeus, Kataibatas, Eranos, Hemithea

Öz: Bu çalışma, modern Bozburun Yarımadası́ndaki antik Tymnos'un merkezinde ve teritoryumunda yerleşik olabilen Karia kökenine iilişkin yerel izleri sorgulamaktadır. Metnin temel amacı, yarımadanın Geç Klasik Dönem'e kadar uzanan Hellenleşmesi boyunca ve Rodos Adası'nın himayesine geçişi sürecinde, Tymnos ahalisinin ve ilişkili ethnosun çeşitli yollarla kendilerini ifade etme şeklini araştırmaktır. Çalışma, yayımlanmış yazıt külliyatına başvurmak suretiyle ve tahmini olarak $2.5 \mathrm{~km}$ yarıçapındaki fiziksel bir etki alanındaki epigrafik malzemenin (ekseriyetle MÖ II - MS I. yüzyıl), in situ olma/olmama durumuna bakmaksızın, mekansal incelemesini ve kabataslak vektörel çevresini sunmaktadır. Sonrasında, en eski sakinlerin oldukça genel bir sosyo-kültürel yapısını, Karların ve antik yarımadalıların kült sistemi aracılığıyla yansıtıldığı üzere kentin asimile olmuş ilahları ışı̆ında ve çeşitli kontekstlerde açıklamaktadır. Tartışmaların rehberliğinde ve sonuçların gösterdiği üzere, kısıtlı ancak düşündürücü belirtiler, tercihen kutsal epithetler, belki siyasi

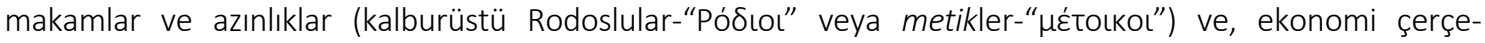
vesindeki isimlerin (ovó $\alpha \alpha \tau \alpha$ ) betimleri üzerinden varılan özyönetim düşüncesi bağlamında bir Tymnosluluk durumu ortaya koyabilir. Buna karşılık, kesin olarak Tymnosluluk kimliğiyle ya da ilgili isimlerle ilişkilendirilebilecek ne bir yer ne de özel bir durum için bütünüyle teşhir edilen bir yerlilik telaffuz edebiliriz.

Anahtar sözcükler: Karia, Peraia, Tymnos, Kutsal Yasa, Hera ve Zeus, Kataibatas, Eranos, Hemithea

Post-Doctoral Researcher, University of the Aegean, Department of Mediterranean Studies, Lab. of Archaeometry and Lab. of Environmental Archaeology, Rhodes, Greece. zedok33@gmail.com 


\section{Introduction ${ }^{1}$}

Ancient Tymnos, a demos (which was probably bigger than a kome) matching modern Bozburun District ${ }^{2}$, lies amidst the Bozburun Peninsula (Fig. 1). It is approximately $40 \mathrm{~km}$ away from modern Marmaris (Physcus). The Peninsula is either articulated as the "Karian Khersonesos" of the Classical epoch or the Rhodian held "Peraia" in the Hellenistic period. We are not sure whether it had different appellation in proto-history but probably had one within the Lukka Land. As explicated by a good many scholars, the "Dark Age" emerged and continued at different speeds and magnitudes in various parts of the Mediterranean and the Ionian Islands ${ }^{3}$. Although there is absence of a direct finding or settlement pattern in terms of the said period, as of today, Tymnos could have experienced more than we expect. Further, the issue of ethnicity which either way involves an exposure to the foreign interventions and demographic turmoils over time or preservation or loss of the codes of a community on account of various factors, is a painful and sometimes tedious job to trace; what we can state for our demos under question is that it was an Anatolian implant by the Classical era while the social identity (basically constructed via ritual mediums) and probably the town character began to change down to the Hellenistic times. This happened with the pacific infiltration of the Rhodian cultural colonization through the implementation of a subtle policy and successful diplomacy and, along with the pursuit of the economy-centric interests.

Presumably valid for all of the Peraian communities, the dispersion of the epigraphical and sepulchral remains, which mostly vanished to eternity, do not signify a specific locus but suggest a domain of concentration due to early travelers' reporting via their selective criteria on the subject matter. Moreover, little inquiry pertinent to the full condition and context of the inscriptions recorded more than a century ago has been made. A second rationale involves some newly released discussions on localness.

Efforts of a number of scholars have enhnaced our comprehension of the fragmentary material, particularly in the onomastic and socio-political context, though. Purely based on a previously

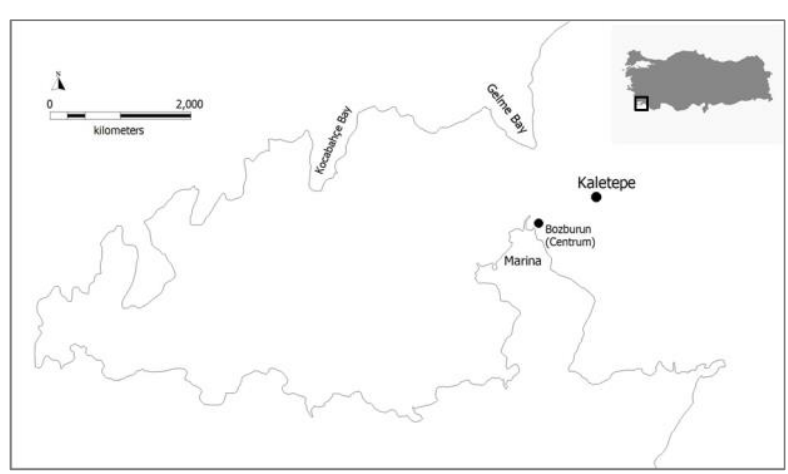

Fig. 1. The position of Bozburun District reported inscription, some fresh inquiries about the presumptive locus of a Tymnian naiskos dedicated to Hera and Zeus has been made, recently. On some stamps, localness was chased by looking at the fabricant prints, in conjunction with the commercial objectives over a region. In the meantime, an exceptional epithet (Ilithyia) was brought forward which is supposed to offer an insight to the assimilated deities in the region, under the influence of Rhodes situated

This paper, except for the novel questionnaires posed hereunder, partially draws upon the expanded versions of some of the themes and observations in the work titled "The Lost Sanctuary of Tymnos: Where Was the Naiskos Dedicated to Hera and Zeus?" published in Journal of Archaeology and Art 151 (2016) 231247 and; some relevant sections discussed in "Three Amphora Stamps From Tymnos (Bozburun, Turkey): A Case Study Regarding Provenance", published in Scientific Culture 3-3 (2017) 31-43.

2 The Peninsula took its modern name from Bozburun District. Karian Khersonesos/ Karian Peninsula is the first known oldest name recorded in literature.

3 E.g. Souyoudzoglou-Haywood 1999, 142-143; Gür 2012, 56. 
opposite to the mainland.

A problem with the corpus of inscriptions is that there is still contraversion with the territorium Tymnos mastered, hence the assignment of some inscriptions [found nearing quasi-inland Losta (modern Selimiye, coastal khora of postulational Hygassos)] to the same domain. Even though some colleagues, referring to the places where the inscriptions were found, locate Tymnos to the boundaries of Selimiye or vice versa ${ }^{4}$, there remains no discussion that the centrum was the modern Bozburun town ${ }^{5}$. It is also beyond dispute that many Tymnians were living either thereabouts or at the Island of Rhodes ${ }^{6}$. In fact, it would be advantageous to plunge into the linguistic rules ${ }^{7}$ through the variations in the usage of certain elements but we have no good chance of doing so. We shall rather prefer to take up localness in light of the available corpus and a selection of the recently published material, as stressed.

\section{Approach and Design}

The basic approach in the study refers to a set of possibilities in the geographical context. The exact find spot of the inscriptions, which have been recovered for the last two centuries in the territorium of modern Bozburun and Selimiye, have not been precisely determined or located. Hence, it is troublesome to foresee their exact loci. Unfortunately, almost none of them are available since they were transported abroad. The majority of the find spots are now within the borders of the modern settlement. Therefore, the vector data visualized on the map (see Fig. 3) shows an estimated areal distribution generated with ArcGIS software. Although the inscriptions are categorized in the coming parts, they are handled as the simply fragmented material (as per monocriteria) on the below map. Since we are poor of an associated or comparative topical

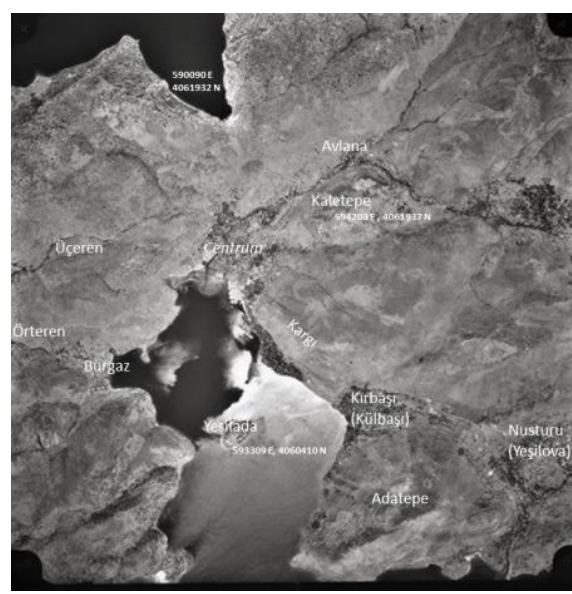

Fig. 2. The major sites and some coordinates on the aerial photograph (dated 1971)

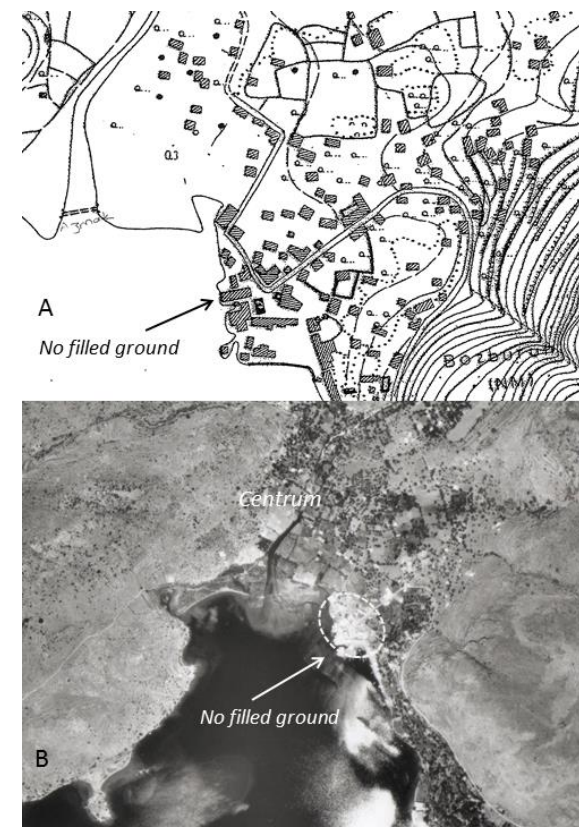

Fig. 2A-B. The area before reclamation ground on 1:5000 scale plot (A); 1:20.000 scale aerial photograph (B) study (which is barely feasible with the use of defacto and dejure knowledge), we shall give it a try from the Peraian or off-demos perspective (where necessary) in the first step and then continue with a Tymnos specific approach.

E.g. Mela I. 16; see also Meyer 1925, 50-51; Fraser - Bean 1954, 62; Bresson 1991, nos. 66-83.

Bean 1971, 162; Fraser - Bean 1954; Peschlow-Bindokat 2003, 11; Oğuz-Kırca 2014a, 278, 282-283.

E.g. see an inscription of 115 B.C, echoing a Tymnian girl who was adopted by a Lindian, perhaps through marriage or another reason. It would be fallacious to pose that her family moved to Lindos and she was adopted there (Rice 1999, 51-52). The floor is blank.

7 For the Anatolian language families and phonology, see e.g. H. C. Melchert, "Historical Phonology of Anatolian". Journal of Indo-European Studies 21 (3-4) (1993) 237-257. 
The paper is designed according to three main criteria, under a broader socio-physical context. It shall attempt, insofar as it is appropriate, to the reader, to traverse some connected sections (of the Peraia) on cult. A quantitative approach is also taken to redisplay acculturation in a micro socio-environment. The onomastic indicators are not left outside albeit few, even rare.

\section{The Physical and Social Context of Inscriptions}

Below is just an endeavor, for the intended inquiry, by dividing the main body into the geographical setting of the demos and exploring into further criteria within the borders or far as the Peraian outlands:

- The spatial position (of the major sites) including the subduction zone and some coordinates (with a visual supplement) (Fig. 2, Zone $35 \mathrm{~S}$ )

- An autopsy on the content of the epigraphical material

a) Onomastic data (basically the epitaphs)

b) Political and cultic indicators

- Spell of other local elements in a variety of contexts (off region evidence, neighboring data, epithets, stamped amphorae).

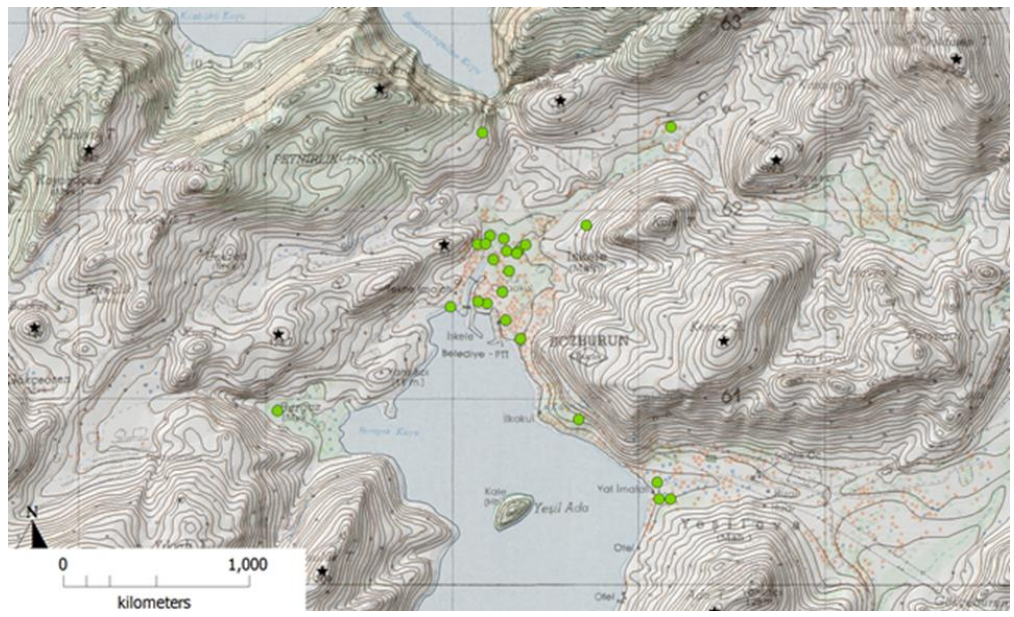

Fig. 3. Estimated areal distribution of the inscriptions on the contour map (1: 25.000)

\subsection{The Spatial Search}

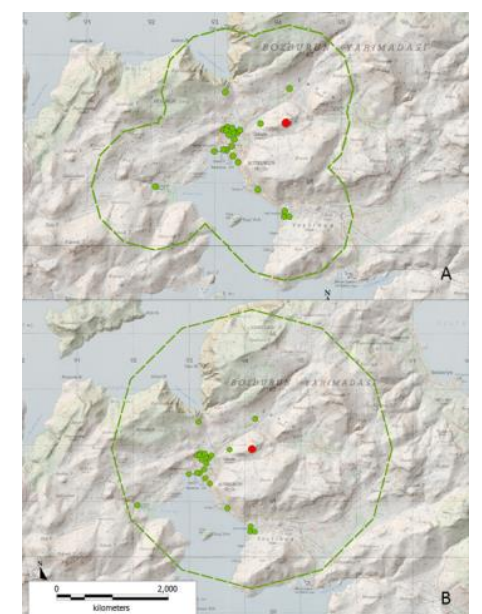

Fig. 3A-B. Buffer zone for all vector data, each within $1 \mathrm{~km}$ radius $(A)$; catchment area of Kaletepe within $2.5 \mathrm{~km}$ radius, adjusted to the farthest data (B) on hillshade map

Referred as a Karian town in the ancient accounts ${ }^{8}$, Tymnos is definitely a pre-Hellenistic toponym. It was part of an autonomous community, the Khersonessians, by the mid/late Classical period ${ }^{9}$. We are already acknowledged with its presence as a settled site through the Hellenistic evidence. Where exactly could Tymnos be and what sort of a settlement was it? We anticipate tackling such matters in detail, in a future study but also recording a brief introduction herein below. It was, without doubt, a place, which had a share of the earthquakes and a khorai-focused settlement in view of its complementary role to the formation of a gigantic khora- the Peninsula itself. The morphology of the Bozburun Peninsula was influenced and

e.g. see Steph. Byz. s.v. Tú $v$ voc; Mela 1. 16; Plin. nat. V. 29.

9 This evokes the very case of the Pelekos community which worshipped the local god Sinuri, near Mylasa, and was ruled through a "direct line" to the Karian satraps (See Williamson 2016, 84). 
altered by the seismic movements in the Aegean, which was exposed to sea level changes over thousands of years. Depending on the dense rock fragmentation, degradation and losses occurred in the sloping and rugged sectors of the terrain (Fig. 4). Observable are the alterations in the littoral morphology around Orhaniye (Kızkumu), Bozburun, Söğüt and Bozuk. Considered with the surrounding geography, specifically the islands in the southern sector, the sea level in Bozburun changed between 0.5-1.0 $\mathrm{m}$, to date ${ }^{10}$. The rise ${ }^{11}$ in the coastal band is well visible over the extension of the mainland falling to the west of the town and the islands (Kızlada and Kiseli $\mathrm{Ada}^{12}$ ). Much as the same in Söğüt and Bozuk where the subduction values range between $30 \mathrm{~cm}-1 \mathrm{~m}^{13}$, Bozburun must also have experienced the similar regarding the coastal settlements. These topics will be deepened later.

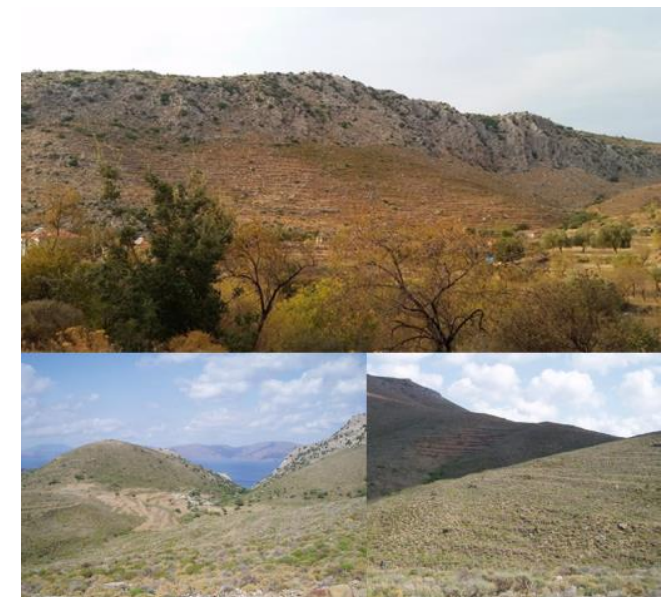

Fig. 4. Land degradation (particularly over the terraced landscape)

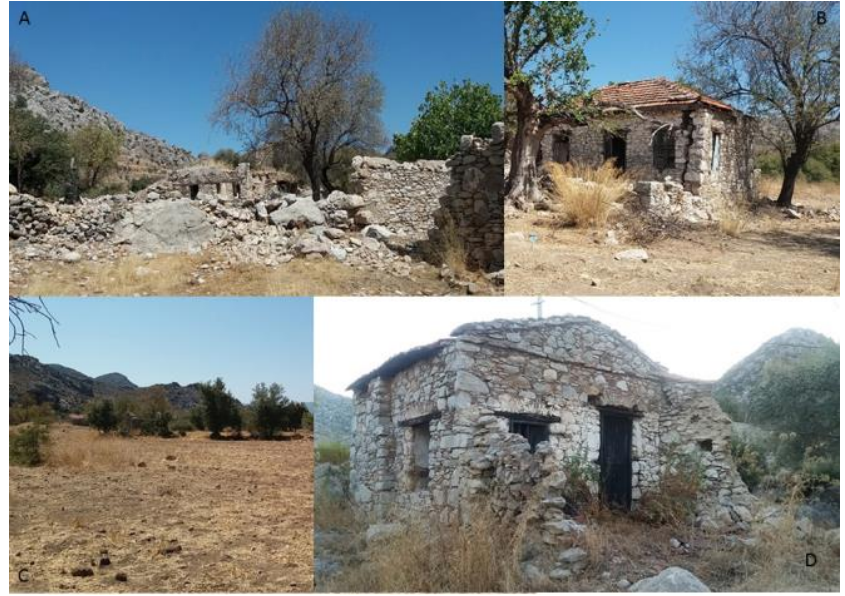

Fig. 5. District of ancient dwellings in Yeşilova (A-C); dwelling near the foothills of Kaletepe (D)

Coastal processes are crucial for understanding sediment supply, tectonism and glacial activity. Two of the innumerable instances come from Lycia and Cilica; the sea level change affected the settled sites in Kekova (facing Simena), sediments greatly shaped the environs of Çukurova (Cilicia Pedias). Since the Holocene, parallel occurrences resulting from the earthquakes affected the Peninsula. Modern Bozburun, which centers round the coastal area, completed its final settlement process by greatly moving from the Yeşilova Quarter (Fig. 2, Fig. 6,C). The filled ground (marked on 1:5000 scale plot and 1:20.000 scale aerial photograph dated 1971, Fig. 2,AB) matching today's Cumhuriyet Square (the heart of the town) belonged to the continental shelf, previously. Some of the inscriptions must have been taken out of the shallow water or found in the near environs. For this reason, we adjust the GPS values for a few of them, as per the distance measured from the limits of the filled area to the coastline.

Along with hillside morphology, which is compatible with terrace agriculture, Bozburun extends in the plain-valley landform, occasionally engirdled with the level areas stretching to

10 Flemming et al. 1973, 48-53.

11 The mentioned rise centered around the spot, locally known as Adaboğazı.

12 Kiseli Ada/Island takes the name from the ruins of a chapel it welcomes. Kızılada is another islet where monolithic blocks and associated remains are conspicuous. Yeşilada, which lies amidst the Bozburun Bay, being the nearest island to the town, houses late period fortification walls. The ramparts, although discrete, can be followed in the western sector of the town, on the mainland and, along the spots approaching the coast.

13 Flemming et al. 1973, 48-53. 
the mini-khorai. Arguably, the plain spaces were formed by way of the agglomeration of the Qal alluvium. It is also conceivable that the current small peninsula- a spit of Yeşilova over which Adatepe rises, was an islet in the geological times; the land became a naturally filled and backdrop area for agriculture-settlement ${ }^{14}$. The terrain stretching from the southern spot of the town center, namely Külbaşı, to Avlana Village does not measure up the ancient settlement practices. The narrow coastal band also beclouds the situation. We interpret that the inscriptions reported form the downtown in $19^{\text {th }}-20^{\text {th }}$ centuries were, on a great deal, the reused material, also implied in the corpus. However, in the words of the local residents, this area was, too, occupied sporadically despite a denser dispersion toward Yeşilova.

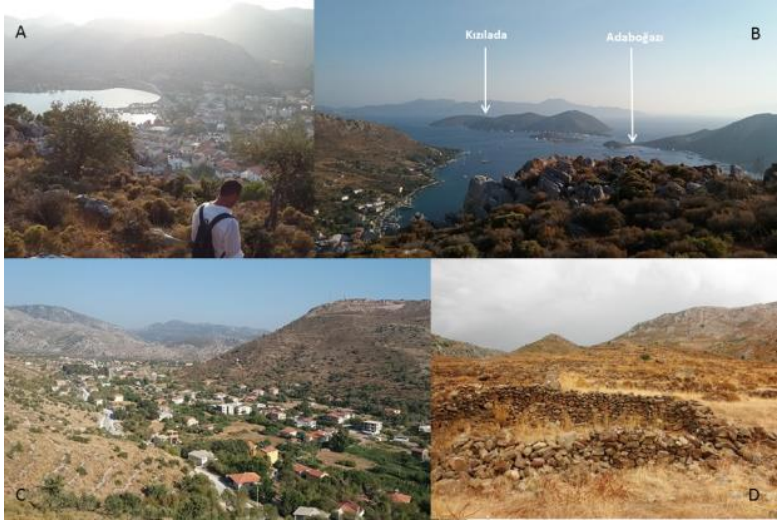

Fig. 6. View of Kargı (A); Kızılada and Adaboğazı (B); Yeşilova/ Nusturu (C); ancient site near Avlana (D)

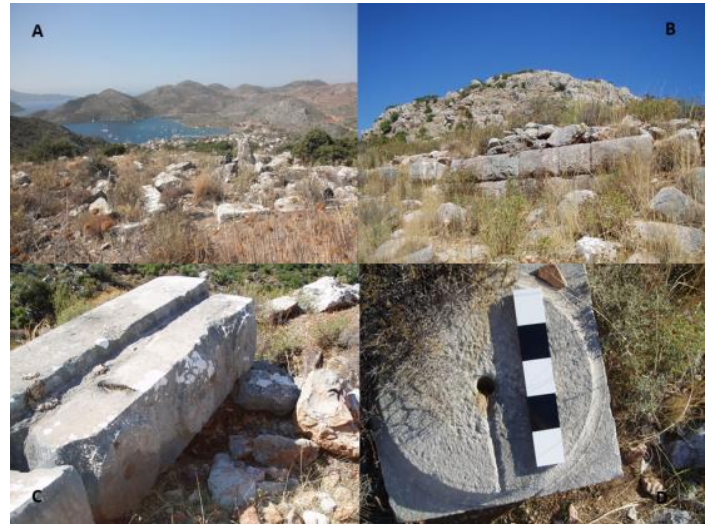

Fig. 7. Base rubbles of a structure (naiskos, tomb?) (A); ashlar masonry (B); pedestals (C-D) at Kaletepe

Another means of approach to the settlement of Tymnos can be taken within the framework of political geography by which the referral to the epigraphical sources becomes an imperative again. The scholars have widely adopted the idea that the political fragmentation of the Peninsula, which fell under the formal patronage of Rhodes during the Hellenistic period, is rooted in possibly the ktoina ${ }^{15}$ practice at the Island. We maintain the opinion that the demoi $i^{16}$ of the region were organized on as equal basis as possible for territorial allocation ${ }^{17}$. Leaving aside the experience on the federative administration and structure by the Karians in the preHellenistic era ${ }^{18}$, the notable evidence for the ktoinai comes from Tymnos and Phoinix ${ }^{19}$. On the other hand, the encounters particularly (except for Rhodes) at Thyssannos (Strapiatai ktoina),

14 "Adatepe" is worth an enquiry by virtue of the name, as well. At the peak and the southern slope lie the traces of two small round plan watch posts appearing with stone masonry are come across. Dating is difficult for both as no surface materials were observed; however, they leave the impression that they could have been actively used until the later periods. As of their high visibility due to positioning, a wide area from Sögüt Bay in the south to the mountainous zone of Selimiye in the north comes into sight from these spots.

15 It denotes the oldest institution for the territorial division of the Island based on the smallest geographical unit (Berthold 1984, 41). A Kamiran inscription of the II $^{\text {rd }}$ century B.C showed that the institution of ktoina was exported to the Peninsula before synoikismos of the three old poleis of Rhodes (Constantakopoulou 2007, 244).

16 Khersonessians.

17 Berthold 1984, 41; Oğuz-Kırca 2015, 37, 40.

18 This could have evolved out of interactive relations as one should also deliberate that the Island could have been affected by the political and economic moves of the Mausolus until her synoikimos and reorganized herself in this direction.

19 Fraser - Bean 1954, 95. 
Tymnos, Karpathos and Halki have brought these places forward as the mini-geographies suggesting a terminus ante quem for the same practice ${ }^{20}$.

Geographically, Tymnos does not inhold heterogeneous land characteristics, but the coastal band needs to be divorced from the inland and mountain peak sites for the broad locational estimates given in this study. Although the primary sources, being the fragmentary material on the general profile of the inhabitants, cast light on what we basically chase, the terrain becomes equally important.

Three major spots ${ }^{21}$, locally known as Nostru/Nusturu (registered as Nostoro on 1: 5000 scale map), Kargı and Örteren address the close districts of the town. The first one addresses the setting flanked with rather the old houses of the indigenous people who live relatively afar the modern nucleus of the town and the yacht pier. It is, however, close to the coastal band; about ten minutes' walk to the shoreline that is full of touristic facilities. The dwellings, originally scattered over the level areas (Fig. 5,A-C) of modern Yeşilova Quarter, form a small district, which is interwoven with the newly built houses. This part, Nusturu, is probably associated with Losta Bay, now identified with modern Selimiye Village. The name must be owed to the cultural relations with the local residents of the khora of Selimiye on its west, which meets the northern/ northeastern sectors of Bozburun town, approaching Avlana ${ }^{22}$ Village [which enables a shortcut route (see Fig. 6,D for some ruins on the route) to Selimiye shores via the plain hilltop site of Gemecitdüzü].

The next domain of attraction and settlement is identified with Kargl, which forms the backbone of the touristic band of the town. With the construction of the modern highway stretching from Selimiye to the end of the pier (forking to the lower and higher road) of the town in 1980s, the center of gravity shifted from Yeşilova/Nusturu to Kargı which is mastered by a series of now abandoned terraces, mostly falling to the backyards of the hotels and pensions. This part, admittedly, is also full of new buildings (Fig. 6,A) that are orderly arranged between the said trails, running from Yeşilova to Gelme Bay/Avlana/the fronts of Çevreli Quarter.

At the rear side, in Tepebaşı Quarter, there appear the ridges of Kaletepe where the archaeological context is rather complex. Scattered in the hillslopes are the ruins of blocks. We are uncertain. Some of the scholars have deemed Kaletepe as a necropolis, which highlights the Karian sepulchral architecture while they did not call attention to a relationship with a settlement. They have linked the stepped stones (bearing semblance to the pyramidal blocks) with the tomb structures. Carter points to a possible Egyptian influence ${ }^{23}$. Based on the recent studies which propose that such stones were mounted, selectively to the public buildings as corner blocks in the ancient settlements of the Peninsula (e.g. ruins of the the lower town scattered over the slopes of the Acropolis in Kızılköy) ${ }^{24}$, we'd better stay off any biased discourse. Many of the Karian style architectural purpose blocks, single or multi-featured

20 Cook 1961, 57-58.

21 Others are a good many: Bük, Adatepe, Gelme, Kocabahçe, Gerence, Apostol, Adaboğazı, Tavşanbük, etc.

22 The name of the village, now a quarter, which is attached to Bozburun, is underscored as Avlanya by Umar 1993, 138. The correct reading as Avlana (according to today's official records) is interestingly associated with a residential quarter of Datça District in the neighboring Knidian Peninsula. Opposing the geographical situation of Avlana, which is quite an arid and waterless environment (disregarding the dried up, temporary stream running amidst the village today), the name possibly comes from Luwian "Aula" (glossed as watery land, Ibid.)- the wetland character of the spot given for Datça.

23 Carter 1982, 181-182 ; Umar 1999, 216. Especially see Carter 1982, for the pyramidal works of the Peraia.

24 Oğuz-Kırca 2014b, 38, Fig. 9. 
pedestals (perhaps the sections of a stylobate), chamber tombs equipped with gate lentos and, defense and terrace walls worked with course faceted polygonal masonry are noticeable over this hilly area. The watch post- predictably a pyrgos, located to the peak, suggests that the spot could have been used as a military character enclosure and that Kaletepe was once a fortress settlement (another watch point lies over Adatepe). On the contrary, when assessed in consideration of the base walls and masonry ruins, the clearly visible plots are meaningful. Indeed, we have, in some degree, an idea as to which periods are attributable to the active usage (inhabited or not) of Kaletepe. As was mentioned above, traces for the occupation of Kaletepe subsist, over a broad chronological band of the Classical/Late Classical, Hellenistic and Roman periods. The remnant of dwellings (Fig. 5, D), although few and currently situated on the hillslopes near the downtown, may support the case.

The final sector, Örteren, was previously used as the seasonal agrosite, lying to the north/ northwest of the centrum. A trackway starts around the front of the modern agora and runs across the valley amidst of which appears a dried up stream and terminates soon before Kocabahçe Bay. The site of Örteren covers the most fragmented terrain in the western part of Bozburun. It is abundant with the ruins of farmsteads that are often enclosed with terraced land and equipped with wells, cisterns, and a cluster of late usage barracks. The westernmost part of the small peninsula, particularly extending from Örteren to Kiseli Ada (Kiseli Island), Mercimek Bay and Apostol Promontory is affiliated with late complex buildings (Fig. 8,A-B) and some wall remains (e.g.

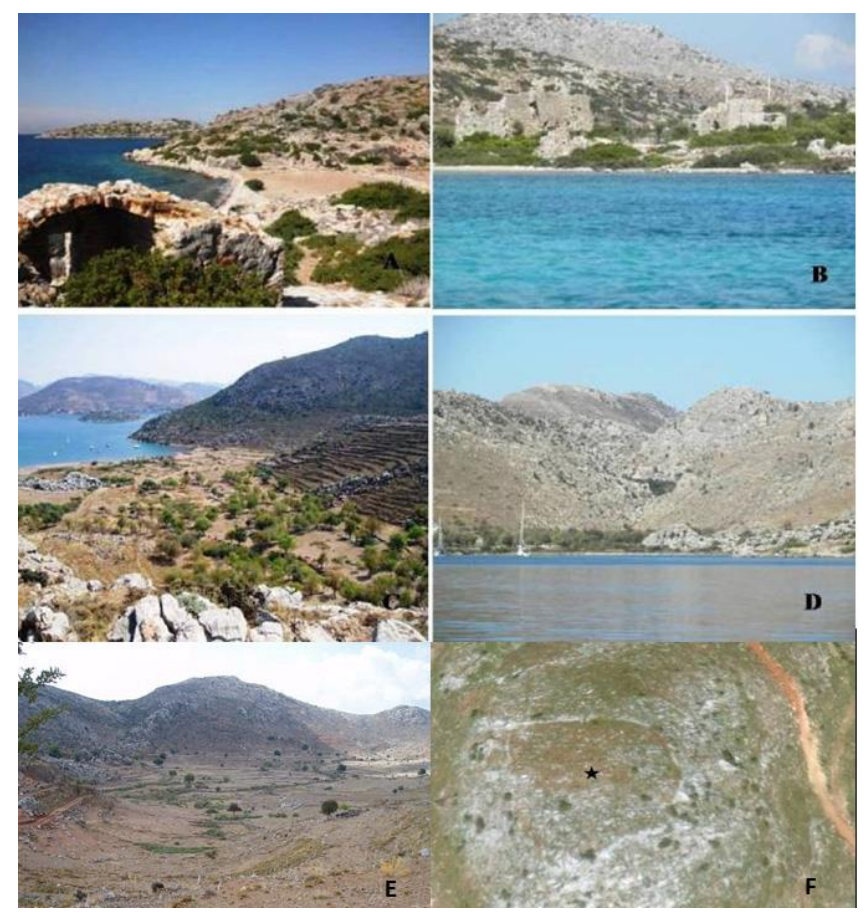

Fig. 8. Late complex (A-B); Örteren and pocket plains (C-E); aerial view of the enclosure on Ayacabük Tepe (F)

Ayacabük Tepe, Fig. 8,F). High up and toward the northern coast (Kocabahçe), small isolated pocket plains occupied with dense but sporadically lain rural buildings may need further questioning. These sites could have had a connection with Örteren (Fig. 8,C-E) and Üçeren. For the entire west, the wells make up the majority of the water feature inventory. In short, the peninsula stretching in the west of Tymnos is a promising landscape, which is expected to disclose knowledge for the late antiquity studies.

\subsection{Epigraphical Search: Tymnos and Tymnians in the Inscriptions}

Dated to a broad chronology encompassing the period between the $\mathrm{V}^{\text {th }}$ century B.C. - I ${ }^{\text {st }}$ century A.D., the intersecting interval of the vast majority of the inscriptions referring to Tymnos is the Hellenistic age ${ }^{25}$. In some of them, the reading of Tupvia (Tymnia, 300/226 B.C)) (if relevant) has

25 Foss - Reger 2000, 948, G4. 
attracted attention ${ }^{26}$. Termera, one of the fundamental settlements in the west of Halicarnassus, could have been the settled city of tyrant Tymnes who was an heir to Histiaeus ${ }^{27}$ in the $\mathrm{V}^{\text {th }}$ century B.C. The word, Tymnos, could have accompanied due to the nuance in the reading of Tymnes; put in other words, the name could stand behind the original toponym. Tymnes $^{28}$ was come across in the ATL, as a Karian ruler ${ }^{29}$ and on a kouros (ca. early $\mathrm{V}^{\text {th }}$ century B.C) found in Athens, as dated to the pre-Ionian Revolt. However, there is not an agreement on its reading whereby Demir also remains skeptical amongst some other colleagues ${ }^{30}$. If so (it had been Tymnes), then there is the speculation that he might have been in Athens for a commercial, military (even perhaps as an epikouros) or diplomatic mission ${ }^{31}$. In a chapter, Herodotus mentions Tymnes who performed a duty, with the service men under his command, in the Scythian palace. Anyone who mulls over the word, "epitropos", might consider Tymnes as a Karian regent and warden at the said palace ${ }^{32}$.

The origin of the name "Tymnos" was also questioned within the context of numismatics 33 ; the readings of TYMNO and TEPMEPIKON on the obverse and reverse of a coin recalls the presence of a dynastic family ${ }^{34}$. We have yet no opinion about a relation or extent of such a case to Tymnos of Bozburun but may brainstorm, though a luxury, that another sub-geography, which finds place further in the south and shares an etymological commonality, can be Bozburun. Unless otherwise proven, this can remain not a norm but a postulate because the Karians were deeply attached to their customs and traditions like many other communities. It is not perplexing that they continued to use Karian origin names during the maturation of the Hellenic codes and stereotypes, particularly toward the $\mathrm{IV}^{\text {th }}$ century B. $\mathrm{C}^{35}$, although the quantity of evidence is too limited $^{36}$. Another associable evidence is the inscription recovered in the vicinity of Kindya; it

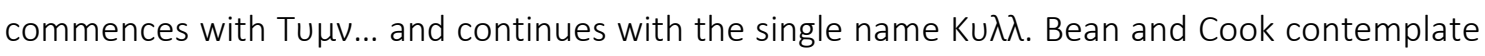

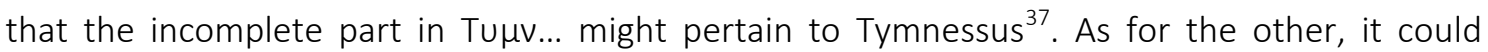
address another Karian city, Kyllandos ${ }^{38}$. Perhaps not directly involved but likely to have relation

26 Bresson 1991, no. 86-87. Equivalent samples were discovered in Kaunos, Pazarlık, Kymisala (SW Rhodes), Telos, Nisyros. The name attributable to Pazarlık was reported from the Sanctuary of Kastabos dedicated to Hemithea and vicinity thereof, which falls into the territorium of Bybassos, a neighboring demos in the Peninsula (Ibid.).

Also note that no.86 and no. 87 (Table 1) are not included in Fig. 3, in this paper.

27 Hdt. V. 37; Bean 2000, 119-120.

28 It is glossed as the "man of Atys/Attys" by Umar $(1993,803)$ while Tymnos (Tu-umna) originates from the "folk of Atys" (Ibid.). Also see Ibid.,136.

29 See e.g. IG I3.71 (I.113-114) (425/4 B.C), IG I .267 (III.25) (445/4 B.C); Demir 2007, 41.

30 Meier-Brügger 1979, 87; Demir 2007, 36.

31 Demir 2007, 38-39.

32 Hdt. IV. 76; Demir 2007, 40.

33 For Karian dynastic coinage, particularly see Konuk 2009, 357-358.

34 Bean - Cook 1957, 143-145. The dynastic tombs are attributable to the sites with vaulted chamber tombs within which $\mathrm{V}^{\text {th }}$ century B.C finds were recovered or those centered around the Ceramic Gulf where the style of tombs suddenly change into rock-cut tombs (Ibid.).

35 See Flensted-Jensen 2004: 1108; Balzat et.al. 2014. Also see Colvin 2004: 45-53, for the Hellenized Lycians.

36 LaBuff 2013, 90.

37 Bean - Cook 1957, 145-146. Stephanus Byzantinus marks Tymnissos/Tymnessos as a polis in Karia (Steph.

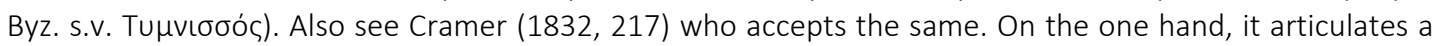
toponym in Lycia (Tuminehi), on the Karian border, which is acknowledged with a sanctuary (See Talbert 2000, 1008 (Map 65) and; Adiego 2015, 404-409 annexed to Kızıl et al. 2015, 406-407).

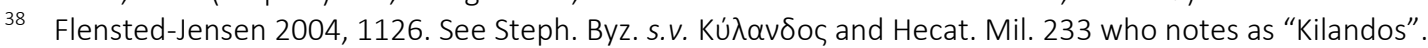


to somewhere around Troas is the short passage given by Schliemann on Khryse and the site of Killa with a sanctuary of Apollo, all probably earthed with alluvium. ${ }^{39}$ Without solid evidence, this is a brainteaser. Despite all, the view that the Tymneses mentioned above are different, also chronologically, than each other, preponderates ${ }^{40}$.

One of the inscriptions bearing a decree character (possibly of the $1 I^{\text {nd }}-1^{\text {st }}$ centuries B.C) was found (in the mid- $20^{\text {th }}$ century) on the wall of a house, no.192 ${ }^{41}$, lying to the south of the pier, in central Bozburun (See Table 1, no.102). Besides the themes addressed and the description of altar objects, the fragment, also known as the Tymnos "Code" (Lex Sacra of Tymnos ${ }^{42}$ ), has received explanation with the presence of a ktoina in Tymnos. The scholars have called to attention the role of a demos and sacrificial activity in the name of a ktoina thereupon. ${ }^{43}$ It has been, even, asserted that the ktoina and demos had equivalent functions in Tymnos. ${ }^{44}$ We will turn back to the point.

\subsubsection{Onomastic Data}

The find spots pronounced in the compiled work of Bresson ${ }^{45}$ are, on a large scale, bound with the expeditions of the early scholars ${ }^{46}$. As we understand, the inscriptions mainly appeared on the funerary epitaphs as well as readings in the political and cultic context. This type of epigraphy also mirrors the impact and extent of acculturation caused by the Greekly but primarily the Dorian world.

Many epitaphs were recorded as the reused materials that were mounted on the walls or facades of the modern dwellings. Something also thorny about the fragmented material is the lack of coordinate information or cartographic visualization. We are aware that, appointing them, though non in situ, to the approximate physical domain can be misleading but this is better than nothing and can light the way to have a general idea about the possible continuation of the habitational pattern as reflected in some ready grounds for any type living. They cannot have gone too far as we will be searching within a pre-defined and lavish enough area for a settled site. Hence, the loci given as "Bozburun" in the corpus are all assumed to have been reported from the centrum or close surrounding unless otherwise stated.

Based on the local articulations stated previously and the given "place" and expressions (if exist) in the corpus of inscriptions concerning the recorded "territorium of Tymnos" (Table 1, Selimiye included), the vector map relevant to the presently vanished or illegally exported inscriptions of modern Bozburun appears in Fig. 3 (through 84-109 and Selimiye exempted). Note that these are the approximate loci, which fall outside Selimiye and the agro-lands that were often created in the most suitable depressions of the fragmented terrain surrounding the centrum and the rest of the districts mentioned above.

39 Schliemann 2014, 44-45.

40 Demir 2007, 43-44.

41 Note that the plate numbers do no pertain to the houses of at least a hundred year old.

42 Sokolowski 1956, 47-50.

43 Mc.Rhod. Peraia. 9; IK Rhod.Peraia. 201; Robert - Robert 1955: 265, no. 210. Also see footnote 19.

44 Jones 1987, 251; Fraser - Bean 1954, 39-40; Bresson 1991, no. 102 (I.4-5).

45 Bresson 1991. Also refer to Blümel 1991.

46 Particularly see Chaviaras - Chaviaras 1911; Chaviaras - Chaviaras 1913; Maiuri 1921-1922; Robert Robert 1955. 
Table $1^{47}$ : The Inscriptions Reported "For" Tymnos

\begin{tabular}{|c|c|c|c|c|}
\hline No. & Type & Place & Date & Remarks/ Reading* \\
\hline \multicolumn{5}{|c|}{\begin{tabular}{l|l} 
Selimiye & \\
\end{tabular}} \\
\hline 66 & Funerary & House, near the church & 400 B.C/200 & a man (Symmakhos, son of Thrasydamos) \\
\hline 67 & Funerary & House & 400 B.C/200 & a family (Hekaton, Eutykhis and lason) \\
\hline 68 & Funerary & School & 400 B.C/300 & a woman (Thais) \\
\hline 69 & Funerary & Coastal church & 300 B.C/201 B.C & $\begin{array}{l}\text { stele on the wall (Symmakhos, son of } \\
\text { Thrasydamos) }\end{array}$ \\
\hline 70 & Funerary & Coastal church & 300 B.C/201 B.C & $\begin{array}{l}\text { on the door } \\
\text { (Damokrates, son of Damatrios) }\end{array}$ \\
\hline 71 & Funerary & House & 300 B.C/1 B.C & Apollonis \\
\hline 72 & Funerary & Unstated (centrum?) & 300 B.C/400 & Theon of Odessos? \\
\hline 73 & Funerary & Near house & 250 B.C/151 B.C & Thrasydamos of Tymnos, son of Damatrios \\
\hline 74 & Funerary & Avlu?/Avlak? Çeşmesi & 200 B.C/101 B.C & Aleksis, son of Polyzalos \\
\hline 75 & Funerary & Near the coastal church & 200 B.C/1 B.C & probably a father and daughter \\
\hline 76 & Dedication & House & 190 B.C/181 B.C & to Artemis \\
\hline 77 & Dedication & House & 190 B.C/181 B.C & to Demeter and Kore \\
\hline 78 & Dedication & House & 190 B.C/181 B.C & to a divinity (...... Tymnios) \\
\hline 79 & Funerary & Çaykuyu Stream & 100 B.C/1 B.C & a woman (wife of Aristeos?) \\
\hline 80 & $\begin{array}{l}\text { Honorary } \\
\text { dedication }\end{array}$ & Unstated & 100 B.C/100 & edge; three fragments \\
\hline 81 & Funerary & Unstated & 50 B.C/100 & $\begin{array}{l}\text { a couple, with raisin ornaments (Damonax of } \\
\text { Tymnos and .... Apollonis) }\end{array}$ \\
\hline 82 & Funerary & Avlu?/Avlak? Çeşmesi & $101 / 300$ & a husband to his wife \\
\hline 83 & Funerary & Coastal church & $151 / 300$ & $\begin{array}{l}\text { a family, inside the church (Onasillos .... and ..... } \\
\text { Ephesias) }\end{array}$ \\
\hline \multicolumn{5}{|c|}{ Bozburun } \\
\hline 84 & Funerary & House & 400 B.C/251 B.C & $\begin{array}{l}\text { Nikainetos Athanodoros, on the wall of a barn of a } \\
\text { Turkish house }\end{array}$ \\
\hline 85 & Funerary & House & 400 B.C/251 B.C & $\begin{array}{l}\text { a couple, on the wall of the same barn, no.84 } \\
\text { (Kleno ..... and Nikainetos ...) }\end{array}$ \\
\hline 86 & $\begin{array}{l}\text { Stamp } \\
\text { "Tymnia" }\end{array}$ & \begin{tabular}{|l|} 
Pazarlık (Kastabos) Kaunos, \\
Nisyros, Kymisala, Telos
\end{tabular} & 300 B.C/226 B.C & clay tile \\
\hline 87 & $\begin{array}{l}\text { Stamp } \\
\text { "Tymnia" }\end{array}$ & \begin{tabular}{|l|l|} 
Pazarlık (Kastabos) \\
\end{tabular} & 300 B.C/226 B.C & $\begin{array}{l}\text { clay tile, might draw up boundaries of the region, } \\
\text { a commercial zone whose centrum was Tymnos }\end{array}$ \\
\hline 88 & Funerary & Avlana & 300 B.C/100 & ostéothèque of a Selgian (Menandros) \\
\hline 89 & Funerary & Kırbaşı (Külbaşı) & 300 B.C/200 & Dionysias \\
\hline 90 & Funerary & House & 250 B.C/101 B.C & $\begin{array}{l}\text { Nikomakhos Epinikos, in the wall of the barn of a } \\
\text { Turkish house }\end{array}$ \\
\hline 91 & Funerary & $\begin{array}{l}\text { Unstated (centrum?, near } \\
\text { the house in no.90?) }\end{array}$ & 250 B.C/101 B.C & Euphaniskos Peisagora \\
\hline 92 & Funerary & $\begin{array}{l}\text { Unstated (centrum?, near } \\
\text { the house in no.93?) }\end{array}$ & 250 B.C/1 B.C & Tharsynon \\
\hline 93 & Funerary & House & 250 B.C/1 B.C & Megakles \\
\hline 94 & Funerary? & Unstated (centrum?) & 250 B.C/100 B.C & ---agidos \\
\hline 95 & Funerary & House & 225 B.C/101 B.C & $\begin{array}{l}\text { of a soldier (Apollonios), the son of ---on), in the } \\
\text { wall of a Turkish house, half an hour to the port } \\
\text { Apollonios who could have died fighting in the } \\
\text { battle against Philip V., however the chronology is } \\
\text { too large to confirm such a case. The author } \\
\text { rightfully remains uncertain. }\end{array}$ \\
\hline
\end{tabular}

47 Bresson 1991. 


\begin{tabular}{|c|c|c|c|c|}
\hline 96 & Funerary & Unstated (centrum?) & 200 B.C/101 B.C & $\begin{array}{l}\text { probably father of Euphaniskos given in no.91) } \\
\text { (Menoitios Peisagora) }\end{array}$ \\
\hline 97 & & School & 200 B.C/51 B.C & $\begin{array}{l}\text { a Pataraean, in the wall of the Turkish school } \\
\text { facing the sea }\end{array}$ \\
\hline 98 & Funerary & House & 200 B.C/1 B.C & $\begin{array}{l}\text { a foreign couple, near the port } \\
\text { (Dionysios of Termessos, Menias of Synnada) }\end{array}$ \\
\hline 99 & Funerary & Kırbaşı (Külbaşı) & 200 B.C/100 & Eisidoros and Eision \\
\hline 100 & Funerary & $\begin{array}{l}\text { Unstated (centrum?, near } \\
\text { house in no.99?) }\end{array}$ & 200 B.C/100 & a family character \\
\hline 101 & Fragment & $\begin{array}{l}\text { At the place called } \\
\text { Nemiste }\end{array}$ & 200 B.C/200 & $\begin{array}{l}\text { contents undetermined, at a little distance to } \\
\text { Bozburun, found in the north of the "Cascade" } \\
\left(\text { Katarraktis }^{48}\right) \text {, on the edge of a well }\end{array}$ \\
\hline 102 & Decree & $\begin{array}{l}\text { House (no.192), in the } \\
\text { south edge of the quay }\end{array}$ & 150 B.C/51 B.C & $\begin{array}{l}\text { Decree of Tymnos about the regulation on the } \\
\text { usage of the sanctuary of Zeus and Hera (Kleinias, } \\
\text { the hierotyhtas) }\end{array}$ \\
\hline 103 & Fragment & House, near the quay & 150 B.C/1 B.C & $\begin{array}{l}\text { Mention of a leader of eranos, on the wall of the } \\
\text { house; was transported to Syme. } \\
\text { Name also appears amongst the amphora stamps, } \\
\text { as a fabricant. } \\
\text { (Mousaios arkeranistas) }\end{array}$ \\
\hline 104 & Altar & House & 100 B.C/1 B.C & $\begin{array}{l}\text { About Zeus Kataibatas; found in the wall } \\
\text { (Dios Kataibata) }\end{array}$ \\
\hline 105 & Funerary & Street & 100 B.C/100 & $\begin{array}{l}\text { a Pisidian, found in the street near the Turkish } \\
\text { school (Skopas) }\end{array}$ \\
\hline 106 & $\begin{array}{l}\text { Honorary } \\
\text { dedication }\end{array}$ & Quay & $41 / 54$ & to Emperor Claudius, found on the quay \\
\hline 107 & $\begin{array}{l}\text { Honorary } \\
\text { dedication }\end{array}$ & Water & $117 / 138$ & to Hadrian, found in the sea \\
\hline 108 & Dedication & Nearby island/ centrum? & $151 / 250$ & $\begin{array}{l}\text { to a benefactor (Estiodoros, son of Estiodoros), } \\
\text { was transported to Syme }\end{array}$ \\
\hline 109 & $\begin{array}{l}\text { Commem } \\
\text { oration }\end{array}$ & $\begin{array}{ll}\text { Pressing } & \text { platform in } \\
\text { Tepebaşı } & \end{array}$ & $501 / 1000$ & $\begin{array}{l}\text { Christian inscription to commemorate the } \\
\text { extension of a church, found as a reused material/ } \\
\text { block on the wall of the pressing platform in } \\
\text { Tepebaşı Quarter }\end{array}$ \\
\hline 110 & Funerary & Zeytinada (Zeytin Island) & 200 B.C/1 B.C & a Xanthian (---- Philippe ...... ) \\
\hline
\end{tabular}

\subsubsection{Political and Cultic Indicators}

Evident from lasos inscriptions, the practices of the prytaneis make sense from the viewpoint of the administrative status of a territory. Regarding the Carian polis model, they were most likely a board of magistrates designed in the Rhodian fashion. Something nearly certain is that the Hellenistic prytaneis were the "presidents of the boule and demos gathered in an assembly". They served on a semester basis, as the case was similar in Rhodes ${ }^{49}$. Models could have been internalized all over the Peraia. Eponymous officials of Tymnos and Amos or a dedication in relation to the deme of Tloans found at Phoinix and their prytaneis now suggest the presence of an earlier form of magistracy before the incorporation of the Peraia and perhaps customization

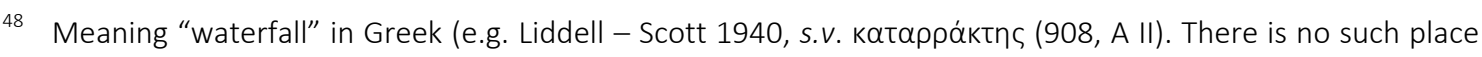
known as "cascade" in or around the downtown. We suppose this could pertain to the temporary stream flowing across Bozburun down to the sea, locally called Azmak gully or the small stream which used to form a pond (according to the seniors of Bozburun) seen from the Roman road heading towards the east of Örteren, (immediate west of Burgaz location).

49 Fabiani 2010, 476. 
of the political codes in the later context. On the one side, the Peraian demesmen were eligible to hold magistracies in the mother poleis and the city of Rhodes, except Lindos, because Athena Lindia was the exception that only the Rhodian demesmen could be nominated for this post along the tribal lines ${ }^{50}$. Although demesmen from the Peraia had the right to participate in the decisions of the sympas demos (as favored by many inscriptions from the $I^{\text {nd }}-I^{\text {st }}$ centuries B.C), the degree of their involvement (including those living on the Island and the Peninsula) within the administrative process is vaguely understood ${ }^{51}$. In brief, the granting of authority to the local administration, as recorded by Strabo, was essentially based on amicable relations accomplished through a successful diplomacy of the Island ${ }^{52}$. No matter, the privileges granted to a dominion emanate from what is non-indigenous or from its degree of relation to a ruling authority.

The ascertainment of the cultic foci of Tymnos becomes difficult without a touch on the belief system of Karia and the Peninsula. The assortment of deities attributable to the Peninsula must have been reciprocated in Tymnos, as well. A novel approach proposed by the author in a recent work involves Asclepius, Hemithea and Zeus Kataibatas ${ }^{53}$. Let us retake a glance at the religious figures briefly before proceeding with the couple figures, Hera and Zeus.

Principally, anyone who tracks the cultic codes of Karia may find them in the rural life. The gods and goddesses were local ${ }^{54}$ and Zeus was worshipped in various forms at many places ${ }^{55}$; the substantial instance was Zeus Labraundos holding his labrys ${ }^{56}$. Although unascertained, the sanctuary, which was the initial gathering religious space dedicated to Zeus Karios, likely stood at the entrance of the Beçin Fortress, rising in the east of Mylasa (modern Milas) ${ }^{57}$. Today, the remaining bases of the structure, which is largely demolished, are visible (Fig. 9).

The head of the gods, Zeus Karios (Kóplos), was widely adopted from the beginning of the $\mathrm{V}^{\text {th }}$ century B.C. A decree of the $I^{\text {st }}$ century B.C. (Mylasa) makes a stress on his wardership of the demoi. Ex-votos of poterion and phiale of 100 and 300 drachmae value were offered in return. As a rule, the social identity of Karios, to whom the votive offerings were made in the form of beasts such as the bull, boar or rooster ${ }^{58}$ was internalized at numerous places. The reputation of Karios began to disappear with the assimilation of Zeus Labraundos in the IV ${ }^{\text {th }}$ century B.C, nevertheless was not kicked aside until the I $^{\text {st }}$ century B.C. Something doubtless is that he was the chief deity of the Karian Koinon which was the highest body of the federative structure ${ }^{59}$ but

50

Fraser - Bean 1954, 123-124. A system of control is partly justifiable through the Gölenye Stele and Amian leases (ibid. 125).

51 Rice 1999, 46, 49

52 Strab. XIV. 2. 5.

53 Oğuz-Kırca 2016, 236, 240.

54 Uyguç 1992, 100-103.

55 Şahin 2001, passim; Küçükeren 2007, 50.

56 Hdt. I. 171; Ratte 2005, 137. Ratte mentions that the local elements disappeared in both Caria and Lydia during the Hellenistic period but their survival in the Roman era needs reconsideration (ibid. 135). There may be a need to further concentrate upon the psychological reasons, e.g. cyclic suppression of some basic facts, which remain unchanged in the cognitive world of the two folks. For example, the continuation of the old administrative canons (e.g. reconstruction of the deme system) which switched to another form in the Hellenistic period can be interpreted as evidencing that these folks did not relinquish their localness completely.

57 Different views prevail pertinent to the topic. See Akarca 1971; Şahin 2001, 68-69.

58 Anyone can meet bulls and goats in the desolate and barren lands of the Peninsula, today.

59 Sokolowski 1955, 154-155, no. 62; Şahin 2001, 68-69. 
the divinities like Apollo ${ }^{60}$ and Artemis perpetuated to be the two significant figures in the sociocultural life, by all the means. The Dorian Hexapolis assembled around the cult of Apollo. The Temple of Apollo at Cnidus was famous enough to attract the masses ${ }^{61}$. The Apollo Sanctuary erected in the second capital of Karia, Halicarnassus, was within the boundaries of the modern fortification ${ }^{62}$. As for the cult of Apollo Erethimios, which is linked with agricultural activity, it was often come across in the neighboring geography, Rhodes ${ }^{63}$. Apollo and Zeus Labraundos are imaged, together with Mausolus, on the coins minted between 366-351 B.C. ${ }^{64}$. The inscriptions, which were retrieved in the Peninsula, particularly at Thyssannos (Söğütköy), Amos (Turunç) and Loryma (Bozuk), also shed light on the Apollo ${ }^{65}$ cult $^{66}$.

Another divinity, which finds equivalence in our study area, is Asclepius, the son of Apollo, which survived as the god of medicine and healing ${ }^{67}$ for ages. No need to convey in detail that Kos is acknowledged as the birthplace of this cult. The noticeable inscriptions were found in Syrna (Bayırköy) and surroundings ${ }^{68}$. The latest sample, which remained intact, is the white marble stone, in the same village, lying at the entrance of the mosque. A previously reported garlanded altar embossed with a snake decoration ${ }^{69}$ gives the impression that it belonged to a priestly genos. A list of Asclepius priests was also found in Thyssannos and Phoinix ${ }^{70}$. An alternative place for the survival of this cult can be the Turgut ${ }^{71}$ Cascade. There is not a precise record of this "katarraktis". Pliny the Elder, ${ }^{72}$ discourses on a spring and hallow in the Khersonesos but it cannot be figured out whether the site so depicted (perhaps "Phausia") ${ }^{73}$ matches here. Southwest Turkey houses plenty of endemic taxa; e.g. storax or oriental sweet gum, which is a highly localized endemic species to the area and even in a limited microclimate at Rhodes (traversing the touristic Valley of the Butterflies), has a favorite habitat in our region ${ }^{74}$. Our patchy habitat, which is restricted to a streambed, occurs along the river valley at the Datça-Bozburun junction (starting of Bybassos, namely Hisarönü), extending to the khora of Turgut. Turgut Cascade- a rather small water source which is highly touristic and shines out with its ecological diversity, and the nearby picnic area are striking with the old, giant-rooted Anatolian sweetgum (liquidambar orientalis) trees (exactly looking like the silk cotton/tithpok (ceiba pentandra) trees at Ta Prohm, Angkor Vat). About the medicine and wellness cult,

60 The impact produced by the Apollo cult in Delphi and Didyma on the ancient world was incontestable and above all.

61 Hdt. I. 144; Bean 2000, 4; Taşdöner 2008, 98.

62 Pedersen 1994, 225.

63 Papachristodoulou 1999, 40.

64 Head 1963, 628-629; Head 1968, 39.

65 The Samnaios cult, which was monopolized by the Apollo priests at Amos, must have been indigenous to this demos (Taşlıklıoğlu 1963, 76; Küçükeren 2007, 45).

66 Fraser-Bean 1954, 22-23; Bresson 1991, nos. 54, 127, 177, 195.

67 Uyguç 1992, 52, 98-109.

68 Fraser - Bean 1954, 28-33; Bresson 1991, nos. 58-59; Bean 2000, 166.

69 Umar 1999, 202.

70 Bresson 1991, no. 118 (I. 1-2); Ibid. no. 148 (I.12).

71 Benter manifests Turgut Village as ancient Hydas or Hygassos $(2010,659)$. We deem it useful to rethink about the connection of this site (about which Mela notes that it might be Hyla (Schoenus) (1. 16)) with the name Hylas who was kidnapped by the nymphs of the spring during the expedition of the Argonauts for the Golden Fleece (Hamilton 1994, 85).

72 Plin. nat. XXXI. 20. 30.

73 Knowledge about this water source is scant and rather inexplicable.

74 See https://www.worldwildlife.org/ecoregions/pa1201 
Hygeia $^{75}$, the daughter of Asclepius, crosses our mind. The liquidambar orientalis, which is medically valued for its oil and balsam, was well known and used by the ancient Egyptians. We might pose the ingenious question whether it could ever have had a relation to the Hygeia cult in the region. In any event, we would not be misguided should we deem Hydas potentially convenient for the sustenance of the cult, as being one of the most advantageous settled sites, like Syrna ${ }^{76}$, due to its proximity to the spring waters, in the Peninsula.

Those interested in the favorite figures of the Hellenistic period are frequently confronted with Dionysus whose cult was, too, amongst the most popular ones in Rhodes ${ }^{77}$. Likewise, the apparent trace addressing the adoption of Dionysus in Phoinix (Fenaket) is highlighted by the single piece, undisturbed inscription carved onto a rocky façade situated on the eastern side of the Acropolis $^{78}$. To the northern part of the Acropolis lies the remnant of a naiskos, which seems to have been dedicated to Apollo while the name of ilithiya (Eileithyia) ${ }^{79}$, the daughter of Hera and Zeus, is recalled ${ }^{80}$ on the same structure. Meanwhile, we identified a highly worn statue head $^{81}$, supposedly of Apollo (Fig. 11,A), as a reused material on the walls of the modern fields facing Kaledağ that rises in the east of Taşlıca Village ${ }^{82}$. This piece could have been transported from an elite structure, which was documented between the respective find spot and Kaledağ. The context is quite distorted on account of the construction work in Taşlıca and the surrounding area and, the heightening use of the new agricultural lands. In any case, we are in a position to propound, by referring to the surface materials found within the boundaries of Phoinix but more than that leaning on the presence of the abovementioned naiskos dedicated to Apollo, that this divinity had the strongest reciprocity at Phoinix, in the Peninsula.

As another, demi-goddess Hemithea (originally Molpadia) cult is conspicuous at Kastabos, the sacred area in Hisarönü- ancient Bybassos. As the scholars attest, the IV ${ }^{\text {th }}$ century B.C sanctuary of Kastabos was built in the Ionic order and initially in the name of Lato ${ }^{83}$; Hemithea was called to attention later $\mathrm{on}^{84}$ : This goddess held the healing power. Diodorus is the first source marking that the inhabitants of the Khersonesos commemorated her ${ }^{85}$. Dependently, the thoughts on the adoption of her as the common cult of the Peninsula ${ }^{86}$ at times, should be accepted normally. Conversely, she is encountered nowhere, except for Kastabos, even not around the sacred area of Lake Kıran (which can be syncretized with e.g. the Panionion) in the

75 Paus. I. 23. 4-5.

76 Umar indicates Syrna as a toponym connotating "sacred water" $(1999,201)$.

77 Gualandı 1979, 130-131.

78 IK Rhod.Peraia, 101; Dürrbach - Radet 1886, 256-258; Bresson 1991, no. 149 (I. 1); Oğuz-Kırca 2014a, 279. On the facade of the stele, the donors for the repair expenses of a temple dedicated to Dionysus are enlisted. On the list of priests found in Phonix, a name demonstrates itself as the representative of the Serapis cult (connected with Egypt) (Bresson 1991, no. 148 (I. 14). Such evidence has a prominent role for disclosing the diversification of the religious beliefs in the Peninsula.

79 She is acknowledged as the goddess assisting the women during childbirth (Hom. XI. 270; Hamilton 1994, 15; Estin - Laporte 2002, 106, 134, 151); recorded as having aided Lato in labor (Paus. I. 18. 5).

80 Dürrbach - Radet 1886, 258-259; Bresson 1991, no. 152.

81 This piece of evidence reminds the cone-shaped Apollo head under the Persian influence as is known through those sculpted for the King of Commagene, Antiochus I, on the western terrace of the Nemrut Mountain.

82 Oğuz-Kırca 2016, 235, Fig. 3A. The village lies in the north of Phoinix.

83 Spratt 1886, 352; Cook - Plommer 1966, 167-168.

84 Cook - Plommer 1966, passim; Bean 2000, 169.

85 Diod. V. 62-63. The author further explains that Hemithea eased the women's labor in childbirth (Ibid.).

86 Cook- Plommer 1966, passim. 
north of Loryma, which has been envisaged as a political and religious purpose gathering place ${ }^{87}$.

Inscriptions with dedications to Demeter and Kore, widely known to Parthenon, over the Athenian Acropolis, were also reported from Tymnos (Table 1, no. 77). Although not directly involved in the subject we are on, there is a need to indicate that we have evidenced, in the territoria of Phoinix and Hygassos, some simulants of the statue base supports (Fig. 11,B) located on the upper side of the crown orthostate blocks ${ }^{88}$, which mirror the Emperor cult in the Roman period and are often seen in the exedras at Rhodes. Such a practice reminds us of the cults by which the Peninsula professionalized in their internalization in every period.

Regarding the above-stated, many unknown figures of the Karian origin Peninsula must have found an expression at Tymnos. Notwithstanding, the epigraphical records do not suffice to announce any other name, apart from Hera and Zeus, by now. For the latter, a piece of

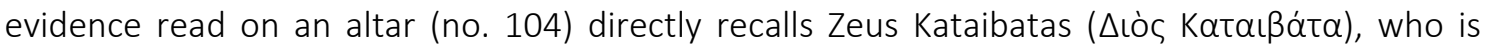
admitted as the master of thunders and warden of domiciles. ${ }^{89}$ This is a very fine sample for representing his adoption under various epithets in Anatolia. We can safely state that he was not foreign to Tymnos, either. This cult ${ }^{90}$ was attested in e.g. Miletos ${ }^{91}$, Pelasgiotis (Thessaly) ${ }^{92}$, Melos and Thera ${ }^{93}$ (Doric Sporades), Arcadia ${ }^{94}$, Anazarbos ${ }^{95}$, but not necessarily being fully "international".

\subsubsection{Other Contexts}

An objective of a previous study was to drive the attention to an in-situ rock-cut votive platform found in 2011, in the territorium of Tymnos and propose a place for a possible now vanished sanctuary dedicated to Hera and Zeus in the ${ }^{\text {Ind }}{ }^{\text {century B.C. }}{ }^{96}$ It also took an opportunity to question the ritual habits of the inhabitants of the Karian Khersonesos at the same time, by bringing the localized patterns and deities (e.g. Kataibatas, Ilithiya contingently transformed from Hemithea, etc.) of "Hellenization" forward in the neighborhood. There is, however, a need to state that we can neither be certain of the precise place of such a naiskos nor the context of the votive platform/ altar, but the lack of announcement, hence the dearth of a possible locus over the level areas to date and; the observation of a nowhere encountered litho-work (in the region) suggests that the platform and its positioning high above an enclave might have related to the pieces of the puzzle ${ }^{97}$. Nevertheless, we have come to realize with this work that the

87 For Kıran, see Saner - Kuban 1999, 289.

88 For the samples, see Çörtük 2013, 249.

89 Chaviaras - Chaviaras 1913, 5, no. 101; Mc.Rhod.Peraia. 70; IK Rhod.Peraia. 202. On the function of thunder or lightning brought to Zeus by Pegasos, see Hes. Th.283-287 (p.70), and a possible link to HittiteLuwian storm god Tarhunta, see the mentions of Santini 2017, 136-137.

90 See Bresson 1991, no. 104; Şahin 2001, 74; Hakman 2013, 10. The cult of Zeus Kataibates was also attested in Miletus. However, the connection between Kataibates and Kataibatas (Burman 1734, passim.) is still uncertain (Şahin 2001, 74).

91 Milet VI,3 1256

92 SEG 47: 674

93 IG XII. 3. 1093; IG XII. 3. 1360.

94 In a tablet, a boy is offered to Zeus, possibly Kataibatas, probably belonging to Lykaion (Heinrichs 2015, 78). Interesting to hear is that the Zeus (Kataibatas?) in Lykaion must have pertained to a local cult, also having a "political relevance" by which case an animal sacrifice was made on the mountain top vis-a-vis human sacrifice according to ancient ideas (e.g. see Paus. VI. 8. 2) (Heinrichs 2015, 8-9). IK Anazarbos 1. 73 (D. 5).

96 Footnote 1.

97 Oğuz-Kırca 2016. 
public context of Tymnos could have approximated the physical surroundings of Kaletepe. Some main bodies of the architectural works and tomb elements have fallen off the hilltop, which awaits to be explored in our approaching campaigns.

The effect and penetration of the pre-Mycenaean culture in the neighborhood of the Peninsula is traceable through handmade coarseware, monochrome vases, curvilinear masonry, simple pits forming chamber tombs and the like. There is little basis, for the moment, for establishing a parallelism in favor of Tymnos, by looking into the burials of the LH IIIC (e.g. the collective "hollow" type tombs as in the case of Cephalonia ${ }^{98}$ ) despite the regional variances in Ionia or the periphery. However, the Peninsula reveals, in part, peculiarities with respect to sepulchral architecture. There is, at the same time, the fact that oblong altars, which were used for the construction of the tombs that leave the Rhodian effect, were exceedingly reported from Bozburun, Karaça, Loryma, Nisyros, Halki and vicinity ${ }^{99}$. The underground structures or chamber tombs occasionally mentioned for the Peninsula ${ }^{100}$ can be seen at Kaletepe (Fig. 10,C) but we must reemphasize that the site could have been initially occupied for habitational purposes. Moreover, Pi shape tombs (Fig. 10, D) and quasi-tomb structures (but possibly nothing to do with storage), for which our studies are also under way, are rather conspicuous on the hillside scatters (Fig. 10, A,B). One might recognize just a semblance, as to their form and shape, to the dolmens found in Thrace. The big question pertains to their yet unfixed function ${ }^{101}$.

Apart from the above given, there are few cases sampling the presence of foreigners in $T_{y m n o s}{ }^{102}$, e.g. Avlana is one place for the reported ostéothèque (funeral casket) of a Selgian along with some others from the Taurus range, perhaps Cilicians, unknown to this region ${ }^{103}$. Bresson provides the epigraphic editions with dates, particularly referring to the Selgians between the $\mathrm{IV}^{\mathrm{th}}$ and $\mathrm{II}^{\text {nd }}$ centuries B.C and the people of Patara from the $\mathrm{II}^{\text {rd }}-\mathrm{I}^{\text {st }}$ centuries B.C. Visible are their origins in Table 1 (nos. 88, 97, 98, 105). Seemingly, this demos had frequent visits from the outsiders and maintained a cosmopolite status in the subject period. A good reason can also be found in the "colonies" of Rhodes from e.g. Soli, Phaselis, Gela ${ }^{104}$, etc.

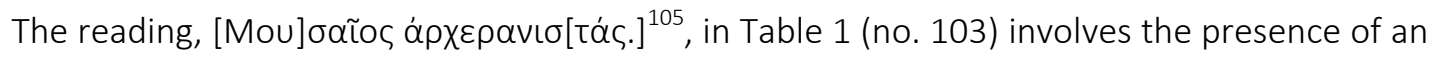
eranos. The eranoi in antiquity could fulfill the function of private-religious groups focused at a specific divinity while they could gather informally to perform a cult ceremony and worship a "foreign" divinity (e.g. Isis, Serapis, Attys, Adonis) or, could have stood outside the recognized cults of a state. The participants could come from minorities or marginal sections such as foreign residents, slaves, affranchises, women, etc. but often from the same lineages or tribes. The costs were met from a commonly shared fund with which religious celebrations and/or feasts were financed ${ }^{106}$.

\footnotetext{
98 Souyoudzoglou-Haywood 1999, 138-141.

99 Fraser 1977, 11-14, 24.

100 Diler 2007, 80.

101 Özdoğan 2006, 143-145.

102 Bresson 1991, nos. 88, 97, 98, 105.

103 Fraser - Bean 1954, 41-42.

104 Hansen - Nielsen 2004, 1390, 1396.

105 Mc.Rhod. Peraia. 202; IK Rhod.Peraia. 205.

106 Foucart 1873, 2-3, 5-7, 10-11, 98, 102, 109. For a known sample, one may refer to Cnidus, reported by M. Newton (Ibid.8-9). As per the inflation of religious organizations in, for instance Piraeus, Rhodes was prolific in the terms of the same (Ibid.110).
} 


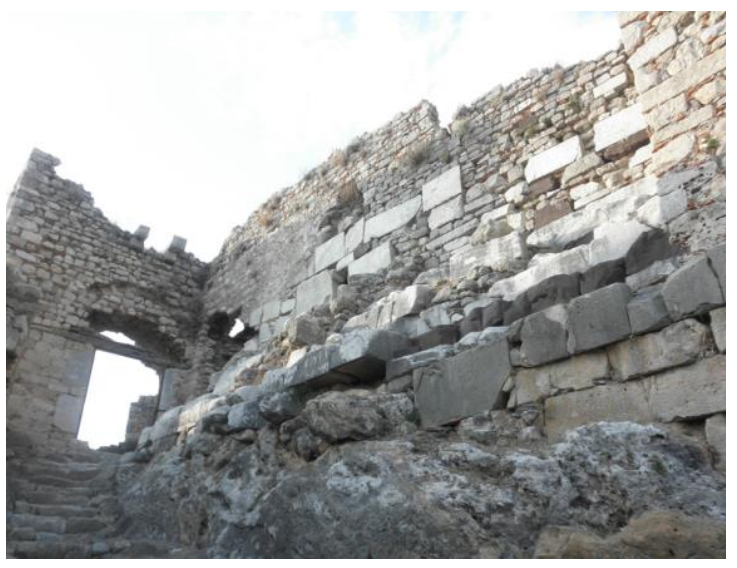

Fig. 9. Remaining bases of the possible sanctuary of Zeus Karios at Beçin Fortress

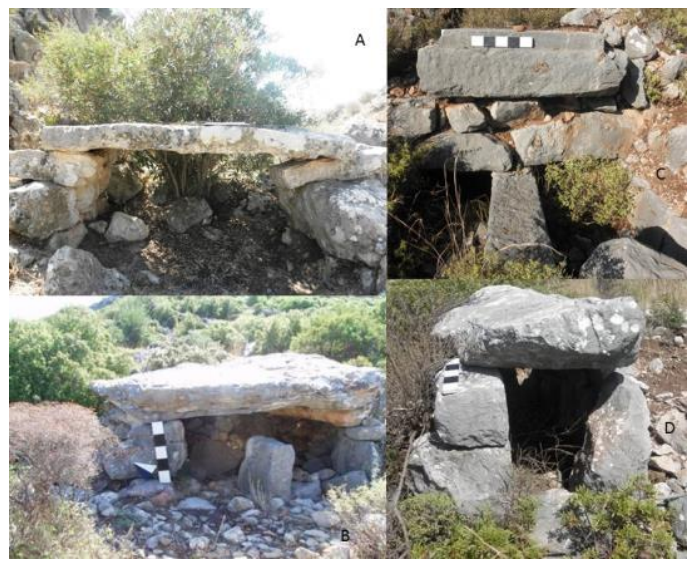

Fig. 10. Quasi-tomb structures/ landmarks (A-B); podest and chamber tombs (C); Pi shape tomb (D) at Kaletepe

Karians were virtuosos in combating. An epigram on a soldier's tomb (III ${ }^{\text {rd }}-\|{ }^{\text {nd }}$ centuries B.C) catches the eye (Table 1, no. 95) along some others; this could have been worked around the dates of the battle against Philip $V$ in the Peraia ${ }^{107}$. None of us can assert with certainty as no other contextual print was conveyed. The chronology is also too broad for a thorough interpretation but Chaniotis elucidates how he was, as the Apollonios of Tymnos, showcased as a Peraian warrior who did not die at the battlefield but was commemorated on his tomb long after he returned his homeland and passed away there ${ }^{108}$. It just reminds another, as of the synchronous date ${ }^{109}$, the Peraia unique pyramidal tomb of Diagoras in Hydas, locally known as Çağ Baba in modern Turgut.

A stamped amphora handle of the fabricant Imas, which was reported by the author of this paper from the lowlands of Kaletepe, was promoted as a recent evidence (Fig. 11,F). The termglocalization ${ }^{110}$ was coined in the same study whereby the inquiry about the stamped objects brought the verisimilitude of the presence of a local fabricant of Tymnos. The find is comparable, as a contra-name, to an adjacent evidence, that of Euphranodiras ${ }^{111}$ (which suggests an organic link with the citizenship of Rhodes).

What makes the difference is that the name, Imas (scened with a caduceus (Fig. 11,E) ${ }^{112}$ ), was previously attested amongst the barbaric by Nilsson who also rejects to put his name (where IMA is not an abbreviation, either) in the Greek onomastics but throws him into the category of indigenous slaves ${ }^{113}$.

107 Bresson. 1991.

108 Mc.Rhod. Peraia.130 (I.13); IK Rhod. Peraia. 209 (I.13); Chaviaras - Chaviaras 1911, 65-66 (no.63); Bresson 1991, no. 95; Chaniotis 2005, 196.

109 Bresson 1991, no.56. The tomb is dated to 300 B.C/101 B.C. (Ibid.)

110 Oğuz-Kırca 2017, 35, 37, 39-40.

111 Ibid.39. Similar names were attributed by Nilsson to purely free Greek patronyms and names (1909, 84).

112 This symbol appears on the upper section of a $1^{\text {st }}$ century B.C. votive relief, framing Hermes (with the nymphs) by pillars with Ionic capitals. The inscription, which now rests in the Archaeological Museum of Rhodes, was found in Kamiros.

Mercury is the equivalent of Hermaios (often depicted with his caduceus (Hom. Il., e.g. XXIV. 343) in the Roman mythology. Caduceus symbol has strong links with trade and prosperity.

113 Nilsson 1909, 89, 99. 
Despite a strong need for multi samples to assert further and establish the comparative criteria as well as adverse approaches of some scholars to the general connectivity of Karian names and ethnicity ${ }^{114}$, Imas should be thought twice as a potential Peraian, perhaps a Tymnian fabricant. We reconfirm that more archaeological evidence should become available to comment on his definite origin. The undecided provenance and the nuances reflected via the linguistic investigation require solid evidence. About the provenance of production or testifiability as per the local traits, any petrographic study seems as a slight chance to help the corroboration of the origins of a workmanship, manufacturing source, etc. on an amphora handle. Although it was priorly suggested in the reverse way ${ }^{115}$, it is to underscore, with this opportunity, that the metallurgical examinations to understand the compatibility of the amphorae attributes with the local geographical and pedological characteristics are now considered to hardly work, thus prove to be useless, totally in view of the many adversely affecting land agents and their displacement over time, as well as the unpredictable effects of tectonism.

\section{Tymnos "Code"}

The "Lex Sacra of Tymnos" is a religious character public inscription. As we comprehend with this fragment, there existed a neopoias (sub-region governor) who was in charge of regulating and caring of a temple dedicated to Zeus and Hera. The decree (150/51 B.C) fundamentally tells of a cult activity in the demos. The action involved the ktoina where it, at the same time, took the form of a banquet in the

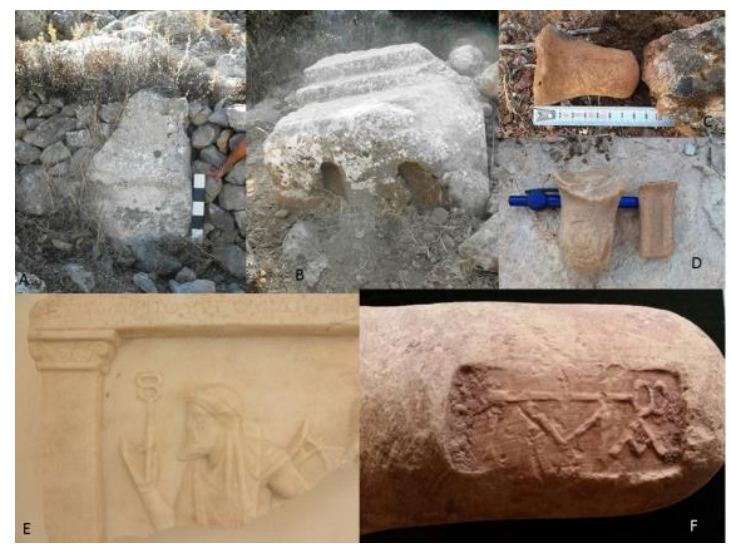

Fig. 11. Head of Apollo? (A); statue base support (B); Hellenistic sherds (C-D); Hermes with his attribute, the caduceus (E); stamp of Imas with a caduceus (F) month of Panamos. This prescriptive evidence mentions that the facilities and the banquet were regulated and managed by the hierothytas ${ }^{116}$ Kleinias, the son of Epigonos and that the use of the stoas in the agora were, presumably, permitted during the banquet, after the sacrificial action. As conveyed, lightening, except for the religious purposes, was forbidden lest it endanger the sanctuary and edifices. The caring of roofs and statues was necessary according to the ordinances on the use of cult services, sanctuaries and public buildings. When not obeyed, a set of sanctions was implemented following the application of a reporting procedure. Those violating the rule were obliged to pay 100 drachmae and bear the cost and expenses of repair or replacement thereof ${ }^{117}$.

Few scholars have commented on this piece of evidence, until recently. Sokolowski puts emphasis on a pre-wedding ceremony accompanied with the spirits of Hera and Zeus whose names were documented in the text. Surely, the author might be interpreting as per the wedding-related missions of Hera. It is, therefore, called to attention, with the reading,

\footnotetext{
114 See LaBuff 2013, 97.

115 Oğuz-Kırca 2017, 40.

116 A magistrate type. As we understand, he had both "religious" and administrative obligations, in the priestly official/ ruler status. Sherk (1990) parallels the hierothytas to the demarkhos in Athens. The hierotyhtas of Tymnos, Kleinias, must have been an eponymous official (287).

117 Mc.Rhodian Peraia.9; IK Rhod.Peraia 201; Robert - Robert 1955.
} 
prothyei $^{118}$, that the offerings were made in the name of both divinities before any wedding occasion. Furthermore, he exemplifies Thera where the religious weddings were performed in the sanctuaries. He, at the same time, makes a stress that the expression of ktoina could imply the acceptance of either spouse to a new cult. Then we pose: Could the wedding and cult occasion coincide or; is it a matter of a cult activity because of a wedding or vice versa? Perhaps, the purpose, as the author attests, was to introduce the either party, who was accepted to a new community, to the ktoina cult and celebrate the religious-like wedding with a dinner that took the form of a banquet. Festivals held on behalf of the ktoina could be a reason for gathering in ancient times ${ }^{119}$. This point is unclear. About what Sokolowski proposed, we might pose that if the gathering activity aimed an acceptance of either spouse to a new community and/or a relational cult, she/he could be e.g. a Rhodian or a local person marrying to a Rhodian living in Tymnos, to a foreigner visiting the demos, etc. as this decree would not normally mention the ordinary people at all. Those interested may come across different divinities with various epithets or names such as Hymenaios, who were responsible for directing the wedding processions in the ancient world. ${ }^{120}$ But, a key name in our decree, without hesitation, is Hera. Also possible is that the names featured in the decree did not necessarily have relation to a ceremony based on a wedding. However, we are inclined toward an alternative herein; this could be an hieros gamos ${ }^{121}$ just like the sacred marriage of the god and goddess, Tammuz (Dumuzi) and Inanna in the Sumerian cosmology ${ }^{122}$. Similar rites are known from many other places; Egypt, Canaan, Crete, Mycenae ${ }^{123}$, etc. where the reenactment of the marriage was regularly performed in springtime ${ }^{124}$ following the fulfillment of the task often by the king/ local ruler/priest of a town. The event of festing could be part of the annual ceremony or people were generally feasted ${ }^{125}$ on or around the day of enactment. The general belief was that the chief god (represented through a ruling personality) would help the divine gift and offer the blessings to live on the fat and abundance. In such a context, our inscription could address a spring festivity, birth of the nature and livestock, celebration of the beginning of the year with good thought and hope.

We definitely remain ignorant whether Tymnos had an agora or there existed a sanctuary dedicated to Hera and Zeus in an agora or any transitional and/or formal function space like a gateway ${ }^{126}$. Maybe, there was no such a structure in the boundaries of Tymnos ${ }^{127}$. However, there remains little doubt for a sacrificial offering. We are also unsure about the existence of an altar in the agora. The offering ritual could have taken place in a temple after the action of sacrifice (of an animal). Putting all aside, neither a sacred building or similarly functioning public structure in association with the names of Hera and Zeus nor a terrace or locus embanked with

118 Meaning "Before the sacrificial action".

119 Sokolowski 1956, 47-50.

120 Eur. Tro. 310.

121 See e.g. Holland 2012, 1.

122 In a narrow context, the wedding preparations are identified with the harvesting of the date palm and cereals (Çığ 2014, 15, 24, 56) representing the romantic entanglement of Tammuz with his wife. At times, such a rite is performed in communities involved with herding (cattle raising and/or sheep and goat breeding, Ibid. 25, 56) as Tammuz, the god of herdsmen and fertility, is not limited to any type agriculture.

123 See Elderkin 1937, 424.

124 Kramer 1958. Also see Hes. Th. 921-922 (p.100).

125 Çı̆̆ 2014, 17.

126 To illustrate, a gateway annexed to a stoa is well known from Mylasa (See Williamson 2016, 94).

127 Sokolowski 1956, 50. 
a temenos area was/could be determined or found until now, at Tymnos. Notwithstanding, we also moot the idea on the presence of indigenous priests and priestesses acting in the name of the said divinities. There is ready information about the spouses or relatives who voluntarily did or were forced to perform this job as per their distinguished status in the Karian and Ionian societies $^{128}$. We might recall, thereupon and once more that, the priest(ess)hood, which began to be practiced, particularly from the beginning of the ${ }{ }^{\text {nd }}$ century B.C (e.g. in Panamareia festival), was fulfilled by the influential families (e.g. the couple from Hierakome), and festivals were held to honor Zeus and Hera (for their symbolic wedding) ${ }^{129}$. Private lands in Karia could even be offered in the form of financial support to the public sanctuaries, in Sinuri, Mylasa ${ }^{130}$. In the Roman period, the new couples often distributed wheat alongside various sacrificial gifts and grants in Confarreatio type marriages. During the premier days, following the nuptial night, sacrifices were made and kinfolks feasted ${ }^{131}$. Any correspondence of Hera or an associate figure, action, etc. was likely in such rites. Interesting but mentally not that far, in one of the iambi of Semonides, one can even find a short mention on the ancient cooks who were good at oracling (as haruspices), hence often managed the wedding rituals and sacrifices ${ }^{132}$.

Given above, the pedestals we observed at Kaletepe could have been the complementary parts of the podium type or terrace graves or were utilized in the privileged, bicolumnar or tricolumnar structures. Some of the grooved drums bear the characteristics of the Roman works whereas the ruins of a higher code structure makes an appearance in the Hellenistic style, with the base stones and terrace walls. Could this vestige have any relation to a sanctuary? We are strictly neutral at this stage. The smooth terrace walls, highlighting bossaged isodomic (Fig. 7,B) workmanship, are noticeable even though this makes it hard to provide a linkage to the matter. Besides, single, double and triple pedestals (Fig. 7,C-D), disassociated to their contexts, can be traced down the skirts of Kaletepe, at rather low elevations. Could these base rubbles originally belong to a public structure, e.g. a naiskos? (Fig. 7,A) Were they otherwise sepulchral elements as some thought $\mathrm{so}^{133}$ ?

An intriguing find is a large and flat stony platform (the rock-cut votive mentioned in 3.2.3) lying at the peak of Kaletepe (Fig. 12). The texture is rather distorted. Locally described as the "blood stone" by the indigenous villagers, it could have been used for sacrificing, in other words as an altar/altar space for the victimization of some beasts ${ }^{134}$ as the backdrop for the culminating event in the name of the divinities. In that case, we are slanted towards the verisimilitude of a connection to the Tymnos Code and expect to carry on the hypothesis with a future study. Additionally, we plan to add to the discussion soon, by evaluating the area shown in Fig. 7,A, which might be linked to a worshipping space/sepulchral structure (not far off the mentioned lithic platform), overlooking the Tymnos Bay having high visibility.

128 Dingil 2006, 12-15, 227-237.

129 Williamson 2009, 214-215; Dingil 2006, 13-15. For the tradition of hair offerings within such scope, see A. Sina, "Karya Panamara'da Bulunan Saç Adakları Yazıtları". Tarih Araştırmaları Dergisi 22 (34) (2003) 125-134.

130 Williamson 2009, 88.

131 Blanck 1999, 193-197.

132 See Semon. Poem 24.1-3; http://www.perseus.tufts.edu

133 See Carter 1982, 178, 193-194; Umar 1999, 216.

134 For a discussion on the official cults related to the sacrificing of dogs and some other beasts (where Tymnos is indirectly addressed) in the late $\mathrm{V}^{\text {th }}-\mathrm{IV}^{\text {th }}$ centuries B.C, see W. Vollgraf, "Une Offrande a Enyalios". Bulletin de Correspondance Hellénique 58 (1934) 138-156. Also see F.T. van Straten, Hiera Kala: Images of Animal Sacrifice in Archaic and Classical Greece. Leiden- New York-Köln 1995. Information comes along with bouthysia/ the oxen sacrifice at Sinuri, Mylasa (Williamson 1996, 92). 


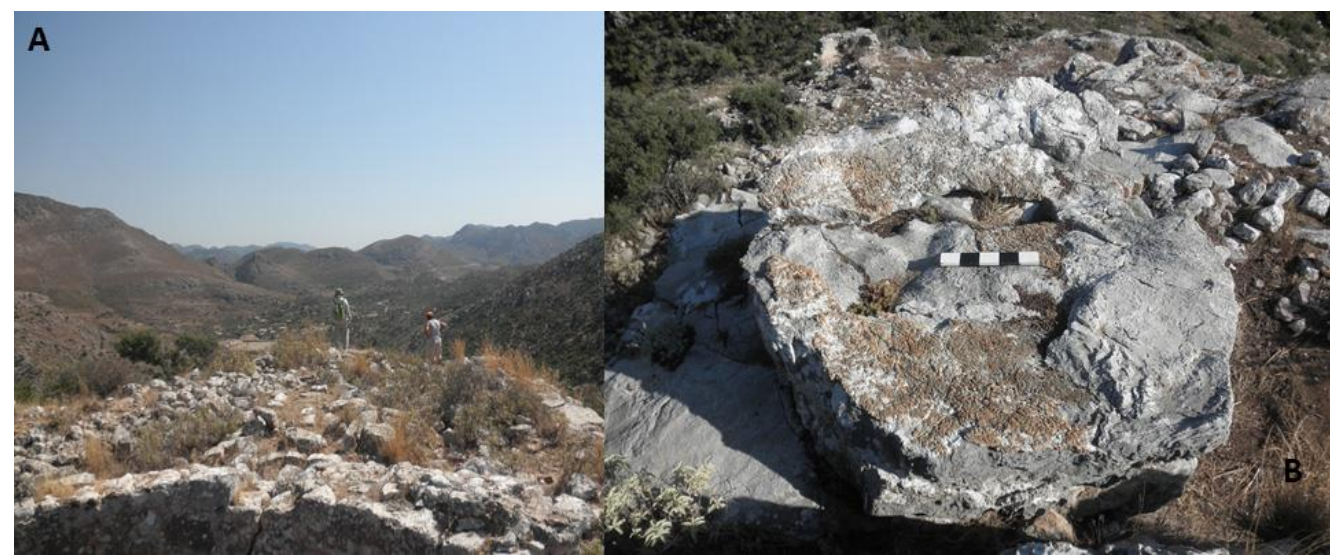

Fig. 12. Peak of Kaletepe and the rock-cut votive platform

\section{The Question of Tymno-Karians?: Were they Tymno-Karians in the Khora?}

What was the basic impetus for the expression of an identity in the Peninsula? Before going into that, one may look at the way in which the Karians perceived themselves or the Karika ${ }^{135}$ was perceived in the Greek world. This is a notorious phenomenon as long as material culture remains and reflects a coherent corpus of the archaeological and historical knowledge. LaBuff reckons, sense of a social and cultural belonging which specially touches the ground through the religious codes, historical accounts and bilingually edited diplomatic context (particularly the decrees and honorary texts) makes the difference to state something more solid vis-à-vis the naming practices, onomastics, erecting decrees, minting coins, etc ${ }^{136}$. Although we might rediscuss the idea totally rejecting the non-effect of onomastics in respect of some rare but "need to reconsider" instances (apart from the overstressed but few cases of the privileged groups, e.g. Histiaeus or members of the Hecatomnid dynasty) ${ }^{137}$, a fifth criterion, might be proposed for the toponymical and/or non-textual (e.g. layout patterns, habitational imprints, ethnographical codes transferred into the modern era, etc.) nomenclature and lemma although these are also separate topics of discussion. Likewise, the mighty figure of Mausolus ${ }^{138}$ and the elite-centric material have always been critical to the discussions selectively centered on the acculturation of this community along with the pacific advent of the Greeks and at the height of the Hellenistic period, thereafter. Many names were either switched to Greek or (in the lack of double names) preferred to be called in Greek (disregarding the illiterate majority of the populations) by reason of intermarriage, conjectural ties as a result of long economic relations in the background, a blend of psychological and political factors, changes in the aesthetic patterns, behavioral shifts on account of admirations for Hellenization ${ }^{139}$, or because they found it fashionable to adopt the Greek way of living, etc. Reasons of "acculturation" are miscellaneous and is not the topic under this study. We hold no specific interest behind the above addressed sample factors for naming/new naming practices in the socially intensified

135 See Apollon. frg.

136 LaBuff 2013, 87-103.

137 Acknowledged as the only "local" dynasty which minted their coins in the course of the IV ${ }^{\text {th }}$ century B.C. (Konuk 2015, 136).

138 See Hornblower 1982.

139 Something noteworthy might be the Seleucid invasions and uncontrolled Macedonian marches, as attested by LaBuff $(2013,99)$. However, this seems to have had far little effect than that of the Hellenization movements as early as the $\mathrm{V}^{\text {th }}$ century B.C and before. 
Hellenistic period. Nevertheless, just as how the elites expressed their identity through the material means, the possible local epithet, Kataibatas, could have been the reprint of a collective desire to remake or not forget themselves and keep the social-ethnic fire constant. Being quite aware of the scarcity of purely Karian or bilingual inscriptions, one should also think that new perspectives need to be opened. As long as the conditions, flow, quality and quantity of new finds permit and we, as the scholars, turn a face to the masses' lives' and unexplored contexts thereof, it can become a meaningful effort to chase localness in the ordinary context.

Something is beyond dispute, at least no dichotomy appears in the ancient accounts; the Karians were skilled at fighting hence were favorable warriors. The traditional canons continued in their social realm. Homeros presents them with the other folks; they were living close to the coastal terrain as well as the communities of the Lelegians, Paionians, Maionians ${ }^{140}$. Herodotus is the first tier source in writing that the Karians, originally being Lelegian subjects- slaves of Minoans, migrated from the Aegean islands to the western coasts of Anatolia and settled in Halicarnassus and Cnidus $^{141}$. Archaeological records supported with cross finds have suggested that they first migrated to the islands and mainland Greece due to population pressures and shortage of land and turned back to their original homeland ${ }^{142}$. No matter who migrated to elsewhere, probably following the Trojan Wars, a strong interaction amongst the Anatolian and Greek cultures, which led to social and ethnic changes for both, is trustworthy ${ }^{143}$.

Many Karian cities are distinguishable with certain elements. Peraia is merely a marginal side- a big khora network in the southwestern tip of Asia Minor. An instance out of sight may be Ouranion ${ }^{144}$. Diodorus of Sicily can influence us for the city as such: a Karian community, in the epoch following the Trojan War, resided at the Island of Syme during the Karian thalassocracy but had to abandon the place due to continuous drought and thereupon migrated to Ouranion in coastal Anatolia ${ }^{145}$. Clearly expressible is that his narration possibly highlights the oral tradition and belief system intermingled with lots of myths and rumors at that age. The location of Ouranion (Uranium) ${ }^{146}$ is insufficiently documented, yet undetermined. But a note of interest might be the positioning of the city, whose layout gives a panorama with the dispersion of the settled plots over a double-top hill ${ }^{147}$ and vicinity. It bears, at least partially, the characteristics of a Lelegian town. Though it may sound weird, this is rather a striking situation from the viewpoint of town planning and spatial configuration of the urban nucleus. A good many Acropoleis in our Peninsula reveal similar plans, ${ }^{148}$ as well as some fortifications in the ringwall type attributable to the Lelegians ${ }^{149}$.

On the matter of ethnic constructs, many discussions continue on the origins of the Lelegians who took part in the Karian history. They were driven from their homes by the Dorians

${ }^{140}$ Hom. II. 10. 428-429 (p.256).

141 Hdt. I. 171.

142 Uyguç 1992, 34-40; Boardman 1999, 23.

143 Küçükeren 2007, 67-69.

144 Plin. nat. V. 107.

145 Diod. V. 23; Bean 2000, 123.

146 Given near Burgaz by Bean 2000, 111, 123. To Varinlioğlu et al., it was in the Ceramic Gulf, on Dikmen Dağ (1992, 156-157).

147 A short mention is also made by Öniz (2010), describing the natural setting of the site between the two hills, at Yalıkavak-Geriş location (54-55).

148 E.g. Oğuz-Kırca 2015, 46, 50.

149 See Radt 1970, 38-65. 
and Ionians. It was since then they took refuge in Karia and were named Karians. Perhaps, they were pro-Hattians ${ }^{150}$. Whatever they were, they had historical and ancestral ties with Karia.

Other sources also leave room to Lelegians about their likely links with mainland Greece; they were believed to be aboriginal, belonged to the same family ${ }^{151}$ with the Karians and settled in several places. Presumably, there was no country called as Lelegia but the folk survived and remained in many lands including Karia. Dionysius of Halicarnassus mentions that it is the old name for the later Locrians ${ }^{152}$. For the Anatolian side, they are identified with e.g. Troas, Pedasus $^{153}$, Syangela, Termera, Aphrodisias (Geyre) in Karia ${ }^{154}$ as well as a few which are appointed to the Peraia, such as Physcus and Larymna ${ }^{155}$. We are poor of knowledge about the way of identification, though. A point of note may be the message of a native, Philip of Theangela in that the Lelegians were the "serfs of Karians"156. Between all those blank lines and a non-predictable relation to the Lelegians, one could pose the question, specific to our case: Were they Tymno-Karians in the Peraian khora?

\section{Discussion and Conclusion}

Presumably, the spatial and political (as well as the political geography) network of ancient Tymnos did not exceed an area of ca. $2.5 \mathrm{~km}$ radius (based on a check, by fitting the farthest vector data to the catchment area of Kaletepe which encompass the mentioned value) of modern Bozburun, but basically meandered the Kaletepe-Avlana-Yeşilova ring, also in consideration of the material culture (Fig. 3,B). The map on top in Fig. 3,A shows the buffer zone for all the "objects" where a radius of $1 \mathrm{~km}$. was appointed to each (spherically ca. $11.76 \mathrm{~km}^{2}$ areal dispersion, measuring ca. 14,26 km perimeter of the shown four-leaf clover form polygon). Upon a simple comparison with the physical domain of $c a .20(19,7) \mathrm{km}^{2}$ in the former, it seems that we had better take this final figure as the sphere of influence being within the acceptable limits ${ }^{157}$ for a small size settlement, by making a revisit to the territorial size categories speculated for the antiquity.

It would be futile to fancy the point shooting of the settled site and identification of the Tymnian folk through the onomastic data. Any place or community in the Peninsula where nonGreek was used far more extensively, cannot be, obviously, put into the status of a socially inferior culture but a truth lies, as is recorded in various ancient texts, in their politically and admittedly economically disadvantaged position to the premium. Language had a correlation

150 See W. Burkert, Structure and History in Greek Mythology and Ritual. California 1979. Also e.g. Iliad for Telepinus, a myth of pro-Hattian?

151 Cramer 1832, 165.

152 Dion. Hal. I. 17.

153 The degree of relationship and/or sameness of the toponyms Pedasus (the Homeric one ascribed to Troad) and Pedasa (the clearly Karian one that flowed into the orbit of Halicarnassus) are ruled out in this text (See Santini 2017, 127-129, for some sound explanations on their usage, localization and interpretation).

154 Strab. XIII. 1. 7; XIII. 1. 56-59; XIII. 3. 1, XIV. 2. 27; See also Cramer 1832, 182-183, 210.

155 http://enacademic.com; https://theodora.com/encyclopedia/l/leleges.html. The credibility of such information is subject to approval by new evidence; however, the works supporting aboriginality in southwest Asia Minor can back up the probability. See e.g. K. W. Deimling, The Leleger: Eine Ethnographische Abhandlung. Leipzig 1862.

156 See the quotation made in the course of the inquiries made for the Lelegian sites and elements by Paton Myres 1896, 270.

157 See Hansen 2004, 71-72. We compulsorily take the "rough" categories as the reference values as the author proceeds with rather general suggestions about the issue of assignment. 
with the Karian identity even though the archaeological material at hand is too scant. However, the Greek names ${ }^{158}$ became the norm and were widely used in the ${ }^{\text {rd }}{ }^{\text {cd }}$ century B.C (despite chronologically distanced cases if all approximate the correct) in the Peninsula. Derivable from Table 1, where the given data are imported from Bresson ${ }^{159}$, the general breakdown of the epigraphical material is dominated by the private Hellenistic inscriptions. Statistically and regardless of a limitation to the modern territorium of Bozburun and diachronic sequence, ca. $65 \%$ (30 out of 45 pieces) evidence belong to the funerary category where a notable number of names, however, predictably goes back to the late $\mathrm{V}^{\text {th }}$ century B.C, including the neighborhoodSelimiye case and Zeytinada. We have no idea for the unknown rest, as these epitaphs must have belonged to the elite portion. Only $11 \%$ (note that five are of the non-Roman period) relates to cults commemorated in the demos.

Karia was never a static community. It remained with some of the unchanged codes (which find expression from architecture to settlement behavior, even with a kind of social inertia, which she could have deemed beneficiary for her survival into the later periods) over the centuries. Tymnos is a demos, perhaps a mini-Karian cultural atelier where the local imprints can be tracked in the Peninsula and a collective strategy of a folk is concealed. It is thanks to the pre-Hellenistic inscriptions that a sound dating could be tuned in favor of the $\mathrm{V}^{\text {th }}$ century B.C. occupants, in the course of the Karian thalassocracy. The scarce usage of certain elements must have been a means, perhaps the only socio-cultural tool, to prevent being detribalized by the intruders, even by the neighboring Rhodes, in the dramatically changing socio-political environments of the Mediterranean. Above all, referral to Greek was indisputably normal due to frequent interaction between the Island and many other sub-lands. Pointedly phrased by LaBuff, the "political landscape ${ }^{160 "}$ and presumably the long-lived economic sharings, which form the omphalos of this deeply rooted phenomenon, can matter to us, from this step onwards. What created the preconditions for speaking or using Greek or acting similarly was the degree of interaction and frequent exposure to each other through various means, including intermarriage and offspring privileges ${ }^{161}$. The view we hold about a second possibility of an intermarriage embedded in the Tymnos Code relates to this situation.

The Classical and Hellenistic territorium of Tymnos seems to have not exceeded far beyond the immediate coast and the area between Kaletepe lowlands and Avlana unless something is reported from over new hinterlands. The lack or little quantity of the epigraphic material (compulsorily regardless of their in-situ character) of the late Roman/Middle Age period and identifiable with the coastal architecture and associated ruins, which quite resemble those documented from rural Syrna, is not that perplexing. The bulk of the engraved finds tends to have dispersion toward the inner parts of the coastal band. This, however, does not put us in the correct context and scientific position as many must have vanished in the same band, as well. A consolation is the possibility of a future find, a medieval fragment amongst the ruins (e.g. the Patakis ${ }^{162}$ site at Adaboğazı (Fig. 6,B) many of which are of the public character (Fig. $8, B$ ). However, this is an area where ceramics (Hellenistic sherds still copiously found, Fig. 11,C-

\footnotetext{
158 On the co-appearance of Greek and Karian names e.g. at Sinuri, see Williamson 2016, 86.

159 Bresson 1991, nos. 66-109.

160 LaBuff 2013, 104.

161 Like an offspring who could be accepted as Jewish through matrilineality by the community or thereby exposed to certain "religious" imperatives with e.g. the bar mitzvah rite.

162 http://www.csb.gov.tr/; Taşlıgil 2008: 79, 81.
} 
$\mathrm{D}^{163}$ ) are not untouched, innumerable terra-cota were erased to the ground.

Something incontrovertible is that Tymnes (an Anatolian personality, and perhaps an ablative of the toponym?) and Tymnos (an Anatolian implant) were Karian. Yet, Tymnos needs reconsideration; it could well be one of the final destinations (of the direct line or branch of the Karian dynasty) where the Karian descendants transported their primordial imprints, which originated from Mylasa- the first capital of the Karian dynasty, to relatively remotest areas on the mainland under rule. In fact, it must not be that remote, in recognizance of Strabo who underscores Physcus being a harbor (in consideration of the other maritime towns or locations, probably the most suitable and largest town) and nearest maritime place to the capital and homeland of the dynasty ${ }^{164}$. We, however, remain skeptical under any condition and leave the floor to the colleagues who wish to discover the line between the factual and presupposition. In any case, the indicators marking Tymnos as originally and strongly being a Karian and surviving the Karian mentality ${ }^{165}$, despite the debates on acculturation which accelerated from the $\|^{\text {nd }}$ century B.C. onwards, are owed to political, cultic and precariously onomastic elements (although limited to a single case) winking in the demos. The limited but primary mottos in this study are a hierothytas' rule in the ktoina, Kataibatas, Imas and perhaps eranos, at the local level. None of the above can, however, be regarded as an archetype of the Peninsula but they are solid and just there. Indigenousness is likely, as in the case of Imas and with a glance to the content of the inscriptions giving clues about the presence of the foreign visitors/ metoikoi in the demos. Hence, ancient "glocalization" is worth reconsideration in light of a few but specific and precious data at hand. Tymnos could be an address, even a heartland of the Peninsula but was a Karian (no matter whether Rhodes or any other aspirer was acting in the Mediterranean market) mediator/ supplier/ etc. in the trade flow network.

That the reading, Tymnia, was retrieved in a number of places, as Bresson also explicates in association with the script of this name, has relation to her place/ membership in a commercial zone. ${ }^{166}$ To put it differently, such a status might originate from the central position in the Peninsula that remained in the Rhodian directed trading zone. We might, therefore, rationalize the rare/ non reading(s)/ spell(s) of Zeus in the Peninsula, except for Tymnos. Equally possible and reasonable, if read in the reverse way, was the commemoration of Zeus, who was acknowledged by multiple communities as the chief of gods, in a frequently visited demos by the foreigners.

The inscription mentioning Zeus Kataibatas (hardly a derivative of Karios, also identified with wardership) might be taken for granted as a remarkable instance for pointing to the local signifiers of Tymnos. When it is reconsidered that the vast majority of the deities reported from the Peninsula are the widely accepted figures, which bear authentic epithets (e.g. Apollo Samnaios in Amos) in a few exceptions, we state that the demoi addressed via the original epithets can match up with a more specific Karian identity. That is, the divinities taking different epithets must have been representing a liberal Karian spirit oriented to the local cult.

At this point, there is a need to make a mention to Ilithyia (Eileithyia)- representing the women in labor which is a powerful comparative figure with another Greek goddess, Hemithea.

163 For a simulant of e.g. Fig.11,D (right), see Henry et al. 2014, 283, fig. 45.

164 Strab. XIV. 2. 23.

165 For a disputable Karian identity during the Byzantine rule in southwest Asia Minor, view Ruggieri 2009, 207216.

166 Bresson 1991, nos. 86-87. 
Hemithea could be/ was a common cult. Hardly as it may seem, an intersection point with that of Phoinix and Kastabos, from our point of view, can be the localness of the cults also underscored for Tymnos. Zeus Kataibatas is a fine instance for the adoption of a generally accepted figure under the local pattern and epiclesis whereas Ilithyia might be a mirror of transformation/ acculturation. To put differently, the cults could also have been subject to reconciliation on the naming practices over time and according to sub-geographies or traditional worshipping forms. The relation of either Ilithyia or Hemithea to labor must not be a coincidence. Moreover, both are female. In that case, Hemithea, in light of the chronology of the corpus epigraphicum, could have been converted to llithyia, who assisted Lato in labor, in the small-scale settled areas or; the goddess might have received pronunciation as Hemithea in the commonly shared spaces. Additionally, that Ilithyia is the daughter of Hera and Zeus ${ }^{167}$ gives pause for the good thought on our witness to the names of this triple (mother, father and daughter) in the same region.

Inhumation, despite shifts over various periods, was a general motive and pattern during the Classical and Hellenistic periods ${ }^{168}$. Many more theories can be developed for the micro territoria of Tymnos where we see the same practice. Should Kaletepe situated in Tepebaş। Quarter be a late occupational area, there is no reason why it would not have experienced some degree of settlement throughout the course of the long Roman history during which the demos center could have flown to the northeast, dispersing over and above modern Avlana. It may be that Avlana Village, where inscriptions were available once, was a core implant or an extension which could be easily controlled from the moderate hill overlooking Bozburun Bay and the rest to further south, down to (the potentially marshland) Yeşilova and Adatepe. The hilly terrains rising in the west of Selimiye provides the convenient shortcut route for communication vis-a-vis the modern highway flowing over Örenyaka-Mantartepe-Gökbel down to modern Selimiye. The center of attraction for Tymnos still seems to be Kaletepe and its surrounding area in the Hellenistic period. Numerous monolithic blocks worked out of limestone verify the case that the site was not somewhere ordinary. It will remain a mystery unless excavation is carried out over the sites full of architectural debris. It could have lost its edge and been used as a necropolis in the later periods since the area is a food for thought regarding the grave types and also as a reminder of the "pillar cult" retrojecting to Knossos ${ }^{169}$.

Surely, there is need for extra evidence. Otherwise, we are easily captured with exaggerated theories, which can venture the immense association of Karia and Crete at any time in various contexts; for instance, Milatos Cave lies in the east of Crete ${ }^{170}$, the Island is already acknowledged with the Lato cult ${ }^{171}$, etc. If pillar cult, which is totally a separate topic, also had continuation in Tymnos, can we try a harder situation whether the Mycenaeans could even have had a finger on Kaletepe, at the same time? There is no cost in posing these questions although one may find it on the limits but the questionnaires we attempt might establish a base for the working hypothesis of a future study. If there emanates anything noteworthy with this pillar cult, the Peninsula can be put as a first step territory before entering further inland ${ }^{172}$.

167 Hes. Th. $921-923$ (p.100).

168 Karlsson 2008, 109.

169 This topic will also be questioned in a separate study, which will be discussed in combination with the general settlement pattern of Tymnos.

170 See Spratt 1865, 113-114. No need to open a discussion on the ancient links between the two, through colonization.

171 See Moore 2013, 114-116.

172 See A. J. Evans, The Mycenaean Tree and Pillar Cult and Its Mediterranean Relations. Cambridge 2013. Also 
Besides, one can also pay attention to the point that the epitaphs, the majority of which became the reused material (fine ashlar) on the walls of the old central houses of Bozburun, were possibly transported from Kaletepe. However, when looked at the density of the column bases, mostly the pedestals and several architectural blocks pointing to a monumental structure, the site can be examined as a space on which a local naiskos/ sanctuary could even be rising. What basically casts doubt on the matter is the non in-situ decree, known as the Tymnos Code.

Neither of us can yet claim the presence of a sanctuary erected in Tymnos but we can point to a possibility unless respective evidence is introduced. With this speculation we seize, it was predictively constructed on a higher position or platform in which case we can suggest a locality in favor of the hillslopes of Kaletepe and the catchment area. Already understood is Bresson's mention of the reporting of Tymnos Code as the reused material from the house no. $192^{173}$ with the help of which we do not seem to overflow the physical zone proposed per se.

A picture on our mind would relate to a Heraeum in lieu of the hypothetical naiskos of Tymnos. But, the festival, which could have been gathered for celebrating a public activity (perhaps by reason of a marriage in June time) alongside the ritual of hieros gamos often associated with the spring season (recalling the ritual habits in the Sumerian cosmology) and perhaps accompanied with hiera kala or; only the hieros gamos for the further expectancy on the proliferation of the forthcoming harvest and products of the livestock, was taking place in the demos. A dichotomy would be to place Hera in lieu of the famous figures of Ishtar/ Astarte/Aphrodite/Venus should this fest be performed for the welcoming of a new year via a sacred marriage in which the god and goddess were impersonated by the (indigenous?) priest (and priestess) one of whom could have been Kleinias. We leave it open to discussion for the readers. However, this must have little effect on our arguments. If it was a matter of a "welcoming to a cult" for either spouse, then we have to rethink on the active being of the Rhodians/the

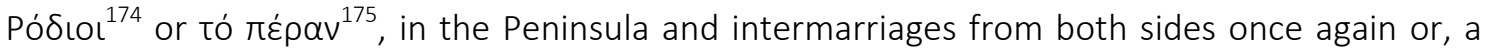
marriage of a Tymnian resident (Greek origin or not, but possibly a member of the elite) with a foreigner.

Though being an outside chance for the region but a figure, perchance, in the religious framework, we can be inspired from Zeus Kataibatas? of Lykaion where an animal sacrifice, visà-vis the offering of a boy/human according to the ancient beliefs, was made on the mountaintop. The locational context, in this case, might be questioned in terms of an interconnectedness between the celebration of the new year via the sacred marriage and the sacrificial activity potentially performed over the rocky votive platform at the peak of Kaletepe and on behalf of the commonly referred figure(s) eternalized in separate inscriptions (no. 102 and no. 104) which demonstrate more or less compatible dates ( $I^{\text {nd }}-I^{\text {st }}$ centuries B.C). A warden of domiciles would also be expected to lead a marriage and ensure its survival whether this be a private one made on behalf of the deities or a communal activity taking the form of a symposion to worship for the abundance and fertility of the landscape belonged.

A postulation is that the hierothytas given in the decree may jibe with the neopoias, as of their tasks. Another contingency is the hierothytas' membership to an influential family of

see small dimensions of Mycenaean shrines.

173 Bresson 1991, no. 102.

174 See van Bremen 2007, 119-120.

175 See Dmitriev 1999, 245-247. 
Tymnos, perhaps holding the priesthood of Zeus and Hera with his spouse. Referring to the Lindian decrees, the management of cults was conducted through ktoinai. There were two traditional ways of financing the cults; throwing the burden on "chorêgoi" (well-to-do citizens) in the form of a tax or imposing tax on the entire population. ${ }^{176}$ An inscription (late III $^{\text {rd }}$ - early II $^{\text {nd }}$ century B.C) found in Rhodes mentions taxation applied for the reconstruction of public buildings following the tectonic disaster in 227 B.C. An analogy (regarding penalty for the renewal or the replacement of public edifices so mentioned) may be drawn with this reference ${ }^{177}$. But in any way, he was presumably equivalent to a local magistrate (if not purely Greek) or prytaneis operating at the local/ ktoina level, from an indigenous folk which might have carried a remote dynastic name (which was commemorated by another fragment; stamp Tymnia).

The eranoi in antiquity, to us, should not be skipped regarding the debated various missions of certain clubs in a society. Hence, the reading in no.103, Table 1 is interesting enough to interrogate primarily the presence of the metiokoi or the serfdom of the Peninsulars, at this point. Kataibatas, which could also be attested in the foreigners' regions recalled on the Tymnian inscriptions ${ }^{178}$, could well be a commemorated cult of the foreign groups forming any eranos in our demos. We come across the reading of eranos in e.g. Thyssannos, Loryma and Kasarae in the Peninsula ${ }^{179}$, lasos and Mylasa ${ }^{180}$. The fragment found in Thyssannos mentions that the koinon of eranistes of Adonis honors the son of Teleson, Telestas. Clear is the explanation

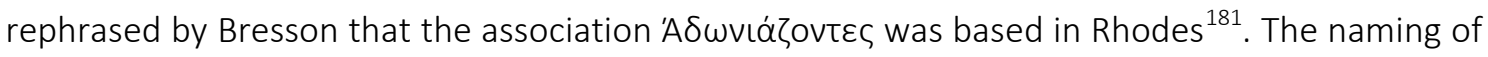
this activity under the koinon concept must be linked to the level of importance attached to the activities (for cult, sacrificing, funding for lending, eating together, etc.) of the groups which often decreed the contributors or leaders ${ }^{182}$. Another sample for the dedications made to the foreigners by miscellaneous associations is attributable to the fragment reported from Turgut ${ }^{183}$. At times of independency in the Peninsula, there were associations, as diagnosed from the Gulf of Syme. It is uncertain whether all of those attributable to Syme were also bound with our territory ${ }^{184}$.

There is, on the other hand, no reason that we should not give some thought to e.g. the Jewish groups (due to the reading, Mousaios) whose activities survived during the Hellenistic period $^{185}$ but this seems to be a remote possibility (even though the name, Mousaios, was copiously found in e.g. Pisidia ${ }^{186}$, Lycia $^{187}$ ) as the sample we have been questioning also displays a slight chance to have spatial and temporal relation to the decree no.102 which retains pagan elements or figures like Hera and Zeus. It should be taken into account that often the Hellenistic elites' pressure on the Jewish groups to bring together Zeus and Yahweh was not welcome

176 Sokolowski. 1958, 139. Further see I. DePrott - L. Ziehen, Leges Graecorum Sacrae. The Sacred Laws of the Greek City-States from the Inscriptions. Chicago 1896-1906 (Repr. 1988).

177 Migeotte - Kontorini 1995, 621-622.

178 Footnote 95.

179 IK Rhod.Peraia 155; IK Rhod.Peraia 12; IK Rhod.Peraia 12; Mc.Rhod. Peraia 110.

180 lasos 361 (I. 6); Mylasa 26 (I. 49), IG XII. 1. 155.

181 Bresson 1991, no. 202.

182 Thomsen 2015, 173-174. Also see Gabrielsen 2001, 164.

183 Bresson 1991, no. 57.

184 Newton 1881, 356-359.

185 Various places in Anatolia were discussed under this topic. See Sivrioğlu 2017, 238-240.

186 E.g. SEG 32: 1298, SEG 41: 1291, SEG 51: 1815.

187 E.g. Lyk.Zwölfgötter-Reliefs 11,A3/4, Petersen-Luschan, Reisen II 57, 110. 
positively at all times ${ }^{188}$. Within this scope, it must concern the indigenous slavery population or the foreigners given in Table 1 or a score of Rhodian origin people operating at the mainland. Almost all the appearing names of the foreigners come from the Eastern Mediterranean where the rising and dying of the gods (e.g. Tammuz transformed to Adonis later or Inanna replaced by Aphrodite in the Greek world) over a year is much known to the scholarly world. If no.103 and no.102 had no relation, then it could have been simply a cult-oriented or social organization the members of which would better remain an enigma to us.

Slavery is another answer in consideration of a good many possibilities for the member profiles. Relying on the mention of Philip of Theangela for a while that it was incumbent on the Lelegian populations in the Karians lands or was, under any circumstance, a reality of the Peraia according to Polybius. As he attests, the inhabitants of the Peraia were "like slaves unexpectedly released from their fetters" when Rhodes was deprived by the Romans of their garrisons in Kaunos and Stratonikeia ${ }^{189}$. Hardly any other place has been depicted as a slave market except the Rhodian Peraia and the Black Sea somewhere nearby Olbia ${ }^{190}$. Should it be a gathering ${ }^{191}$ of the slaves (which could be a religion based group, having the common preoccupation via the localized platforms, at the same time), the inscription under question could refer to a collective ceremony celebrated to cement the indigenous relations for the members, regardless of genealogy and ethnicity.

Tymnos was searched in relatively distant areas (around lasos) rather than being reconsidered with her membership to the Termera koinon ${ }^{192}$. Notwithstanding, we speculate as such for a while; what if Termera, of the known Lelegian cities and a nest to the son of a Karian tyrant ${ }^{193}$, had any relation to Tymnos due to syngeneiai to Tymnes? Can anybody question a remote connection of our Tymnos with the Lelegians or an ultimate effect thereof? Under such theoretical warm up, might "Lelegiannes" be the keyword to which e.g. Pedasus and Physcus were also subject although the literature is yet arbitrary for Physcus. What about the commonalities in the layout patterns (e.g. with that of Ouranion) usually embodied in the double peak Acropoleis?

A set of circumstances takes us to the idea that this demos did not drift away its original identity in contrast to the Hellenization process. A far cry from Halicarnassus, though, the cultural scenario we proposed throughout this paper evokes the reinterpretation of the "pride of Halikarnassos" and "Salmakis inscription" in favor of the cultural memory of the city shaped by the poem therein and the folk etymology ${ }^{194}$. Even though the approach we adopt may appear to be a result of an inductive system of thought, we hold the view that the principal clues repose on the word "Tymnians", denoting a sense of autonomy, engraved in the decree (no. 102) and Kaletepe. As it seems, a potential Hera and Zeus Sanctuary could be, in some way, rising over the Acropolis; the sacrifices, for any purpose whatsoever, were made on the altar at the peak and; the downward flow of a ritual could have been performed for the offerings. There

188 Sivrioğlu reminds us of the general attitude of the Hellenistic elites toward a Jewish community, conveyed by the pagan writers $(2017,240)$.

189 Polyb. VI. 30. 21,24.

190 O’Brien 2007, 40.

191 Then comes to mind the syngeneia of Pormounos that gathered around the sanctuary of Sinuri, on an annual basis, by analogy and their common practice of sacrificing the expenses of which was met by the sanctuary, at Mylasa (See Williamson 1996, 91, 93-94).

192 See Demir 2007, 44.

193 Footnote 27.

194 See Santini 2017: 110-111, 134-136. 
is absolutely a need for decipherable litho-works or skipped fragmentary material on which the ethnos and members are well described. Many others elements call for justification and those yet unrecovered are hoped to unravel the mysteries of our demos. We might seem to have overstated a demos like Tymnos but we, as being those particularly operating in the rural side of archaeology, need to understand and explain further about the ordinary peoples and contextual matters via the theoretical and practical tools as the devil may at times be in details; hidden in the unimagined or less seen in the case of Tymnos. It would not be weird to seek correlations, even when not limited to the cult context, between the fragments as the vast majority has survived under favour of the elites so addressed, to date. Tymnos must speak volumes for the coming time. What is engrossing is the novel open-air wedding-ceremony hall now lying over the site we proposed, just in the modern area, nearby the projection of the Acropolis. 


\section{BIBLIOGRAPHY}

\section{Ancient Sources}

Apollon.

Diod.

Dion. Hal.

Eur.

Hdt.

Hecat. Mil.

Hes.

Hom.

Mela.

Paus.

Plin. nat.

Polyb.

Semon.

Steph. Byz.

Strab.

Modern Sources

Akarca 1971

Balzat et.al. 2014

Bean 2000

Bean-Cook

Benter 2010

Berthold 1984

Blanck 1999

Blümel 1991

Boardman 1999

Bresson 1991

Burman 1734
(= Apollonius Aphrodisiensis, Karika .frg.) Fragmenta. Ed. K. Müller. Paris 1870.

(= Diodorus Siculus, Bibliotheca historica) Diodorus of Sicily 3: The Library of History (Books 4.59-8). Trans: C.H. Oldfather. London 1939.

(= Dionysius of Halicarnassus, Antiquities Romanae) The Roman Antiquities (Books 1-20). Trans: E. Cary. Cambridge 1960 (The Loeb Classical Library).

(= Euripides, Troiades) Troyalı Kadınlar. Trans: S. Sandalcı. İstanbul 2002. The Trojan Women. Trans: E. P. Coleridge (Vol. I) 1891. Accessed from: http://www.perseus.tufts.edu/hopper/text?doc=Eur.\%20Tro.

(= Herodotus, Historiai) Herodot Tarihi. Trans: M. Ökmen. İstanbul 2002.

(= Hecataeus of Miletus, Scylacis Caryandensis Periplus) Hecataei Milesii Fragmenta: Scylacis Caryandensis Periplus. Trans: R. H. Klausen. Berolini 1831.

(= Hesiodos, Erga kai hemerai, Theogonia) İşler ve Günler, Tanrıların Doğuşu (Works and Days, Theogony ( $2^{\text {nd }}$ ed.). Trans: F. Akderin. İstanbul 2014.

(= Homeros, Ilias) Ilyada (Iliad) $\left(23^{\text {th }}\right.$ ed.). Trans: A. Erhat - A. Kadir. İstanbul 2007.

(= Pomponius Mela, De Chorographia) Chorographie (Livres 1-3). Trans: A. Silberman. Paris 2003.

(= Pausanias, Hellados Periegesis) Guide to Greece (vol. 2): Southern Greece (Books 3-8). Trans: P. Levi. England 1971.

(= G. Plinius Secundus Maior, Naturalis Historia) Natural History (Vols. I-X; Books 1-37). Trans: H. Rackham, W. H. S. Jones and D. E. Eichholz. London 1949-1954.

(= Polybius, Historiai) The Histories (Vol. 6; Books 28-39). Trans: W. R. Paton. London 1927.

(= Semonides) Semonides ve Altı lambos Şairi (Semonides and Six lambus Poets), Siirler- Bütün Fragmanlar (Fragments). Trans: Alova, Ed. H. Koçak. İstanbul 2016.

(=Stephanus Byzantinus, Ethnika) Ethnika (Stephani Byzantii Ethnicorum Quae Supersunt Ex Recensione Augusti Meineke). Graz 1958.

(= Strabon, Geographika) Geographika: Antik Anadolu Coğrafyası (Books 12-14). Trans: A. Pekman. İstanbul 2005.

A. Akarca, "Beçin". Belleten 35 (1971) 1-37.

J. S. Balzat - R. W. V. Catling - É. Chiricat - F. Marchand, A Lexicon of Greek Personal Names: Volume V.B: Coastal Asia Minor: Caria to Cilicia. Oxford 2014.

E. Bean, Eskiçağ'da Menderes'in Ötesi (Turkey Beyond the Meander). Trans: P. Kurtoğlu. İstanbul 2000.

G. E. Bean - J. M. Cook, "The Carian Coast III". The Annual of the British School at Athens 52 (1957) 58-147.

M. Benter, "Hydas: Bozburun Yarımadası'nda Müstahkem Bir Yerleşim Yeri". Belleten 74/271 2010) 659-672.

R. M. Berthold, Rhodes in the Hellenistic Age. Ithaca - London 1984.

H. Blanck, Eski Yunan ve Roma'da Yaşam. Trans: I. Tanrıkut. İstanbul 1999.

W. Blümel, Die Inschriften der Rhodischen Peraia. Bonn 1991.

J. Boardman, The Greeks Overseas: Their Early Colonies and Trade. London $1999^{4}$.

A. Bresson, Recueil des Inscriptions de la Pérée Rhodiene (Pérée Intégrée). Paris 1991.

P. Burman, Petri Burmanni Vectigalia Populi Romani, et Zeus Kataibates sive Jupiter Fulgerator. In Cyrrhestarum Nummis, curis secundis illustrata. 
Burkert 1979

Carter 1982

Chaniotis 2005

Chaviaras - Chaviaras 1911

Chaviaras - Chaviaras 1913

Constantakopoulou 2007

Colvin 2004

Cook 1961

Cook - Plommer 1966

Cramer 1832

Çığ 2014

Çörtük 2013

DePrott - Ziehen 1896-1906

Deimling 1862

Demir 2007

Diler 2007

Dingil 2006

Dmitriev 1999

Dürrbach - Radet 1886

Elderkin 1937

Estin - Laporte 2002

Evans 2013

Fabiani 2010

Flemming et al. 1973

Flensted-Jensen 2004

Foss - Reger 2000

Foucart 1973

Fraser 1977

Fraser - Bean 1954
Leidae 1734.

W. Burkert, Structure and History in Greek Mythology and Ritual. California1979.

R. S. Carter, "The Site on Losta Bay". MDAI (I) 32/ 1 (1982) 174-175.

A. Chaniotis, War in the Hellenistic World: A Social and Cultural History. USA 2005.

M. Chaviaras - N. Chaviaras, --- Archaiologike Ephemeris (AE) 58 (1911) 64-65.

M. Chaviaras - N. Chaviaras, --- Archaiologike Ephemeris (AE) 101 (1913) 5.

C. Constantakopoulou, The Dance of the Islands: Insularity, Networks, The Athenian Empire, and the Aegean World. Oxford 2007.

S. Colvin, The Greco-Roman East: Politics, Culture, Society. Cambridge 2004.

J. M. Cook, "Cnidian Peraea and Spartan Coins". The Journal of Hellenic Studies 81 (1961) 56- 72

J. M Cook - W.H. Plommer, The Sanctuary of Hemithea at Kastabos. London 1966.

J. A. Cramer, A Geographical and Historical Description of Asia Minor (With a Map) (Vol. II). Oxford 1832.

M. İ. Çı̆̆, Inanna'nın Aşkı: Sümer'de Inanç ve Kutsal Evlenme. İstanbul $2014^{9}$.

U. Çörtük, "Kaunos'taki Quintus Vedius Capito Anıtı". Cedrus I (2013) 241260.

I. DePrott - L. Ziehen, Leges Graecorum Sacrae. The Sacred Laws of the Greek City States from the Inscriptions. Chicago 1896-1906 (Repr. 1988).

K.W. Deimling, The Leleger: Eine Ethnographische Abhandlung. Leipzig 1862.

M. Demir, "Karyalı Tymnes", Arkeoloji ve Sanat Dergisi (Journal of Archaeology and Art) 29 (2007) 35-50.

A. Diler, Kedrai (Sedir Island). İstanbul 2007.

F. Dingil, Principatus Devri Karia'sında Leiturgia ve Arkhe Üstlenen Kadınlar. Yayımlanmamış Doktora Tezi, Ankara Üniversitesi. Ankara 2006.

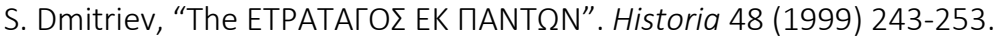

F. Dürrbach - G.A Radet, "Inscriptions de la Péréé Rhodienne". Bulletin de Correspondance Hellénique 10 (1886) 245-269.

G.W. Elderkin, "The Marriage of Zeus and Hera and Its Symbol". American Journal of Archaeology 41/3 (1937) 424-435.

C. Estin - H. Laporte, Yunan ve Roma Mitolojisi (Le Livre de la Mythologie Grecque et Romaine. Trans: M. Eran. Ankara 2002.

A. J. Evans, The Mycenaean Tree and Pillar Cult and Its Mediterranean Relations. Cambridge 2013.

R. Fabiani, "Magistrates and Phylai in Late Classical and Early Hellenistic lasos". Eds. R. van Bremen - J.-M. Carbon, Hellenistic Karia: Proceedings of the First International Conference on Hellenistic Karia. Paris (2010) 467482.

N. C. Flemming, N. M. G. Czartoryska - P. M. Hunter, "Archaeological Evidence for Eustatic and Tectonic Components of Relative Sea Level Change in the Southern Aegean". Eds. D. J. Blackman, Marine Archaeology. London (1973) 1-67.

P. Flensted-Jensen, "Karia". Eds. M. H. Hansen - T. H. Nielsen, An Inventory of Archaic and Classical Poleis: An Investigation Conducted by the Copenhagen Polis Center for the Danish National Research Foundation. Oxford (2004) 1108- 1137

C. Foss - G. Reger, "Map 61 Ephesus Introduction, 1994 (vol. 2, part 4: Graecia-Asia Minor)". Ed. R. J. A Talbert, Barrington Atlas of the Greek and Roman World. Princeton (2000) 937-957.

P. Foucart, Des Associations religieuses chez les Grecs: Thiases, Éranes, Orgéons. Paris 1873.

P. M. Fraser, Rhodian Funerary Monuments. Oxford 1977.

P. M. Fraser-G. E. Bean, The Rhodian Peraea and Islands. London 1954. 
292

Gabrielsen 2001

Gualandı 1979

Gür 2010

Hakman 2013

Hamilton 1994

Hansen 2004

Hansen - Nielsen 2004

Head 1963

Head 1968

Heinrichs 2015

Henry et al. 2014

Holland 2012

Hornblower 1982

Jones 1987

Karlsson 2008

Kızıl et al. 2015

Konuk 2009

Konuk 2015

Kramer 1958

Küçükeren 2007

LaBuff 2013

Liddell - Scott 1940

Maiuri 1921-1922

Meier-Brügger 1979

Melchert 1993

\section{E. Deniz OĞUZ-KIRCA}

V. Gabrielsen, "The Rhodian Associations and Economic Activity". Eds. Z.H. Archibald, J. Davies, V. Gabrielsen - G. J. Oliver, Hellenistic Economies. London - New York (2001) 163-185.

G. Gualandı, "Sculture di Rodi". Annuario della Scuola Archeologica di Atene 54 (1979) 7-261.

B. Gür, "Anadolu'da Geç Hellas Dönemi”. Edebiyat Fakültesi Dergisi 1/1 (2012) 55-76.

M. Hakman, "Bir Anadolu Tanrısı Olarak Zeus'un Tabiat ile İlişkisi Üzerine Bir Gözlem". Acta Turcica 5/1 (2013) 1-18. Accessed from: www.actaturcica.com

E. Hamilton, Mitologya. Trans: Ü. Tamer. İstanbul 1994?

M. H. Hansen, "Introduction". Eds. M. H. Hansen - T.H. Nielsen, An Inventory of Archaic and Classical Poleis: An Investigation Conducted by the Copenhagen Polis Center for the Danish National Research Foundation. Oxford (2004) 3-150.

M. H. Hansen - T. H. Nielsen, "Part III: Indices". Eds. M. H. Hansen - T. H. Nielsen, An Inventory of Archaic and Classical Poleis: An Investigation Conducted by the Copenhagen Polis Center for the Danish National Research Foundation. Oxford (2004) 1253-1396.

B. V. Head, Historia Numorum: A Manual of Greek Numismatics. London 1963.

B. V. Head, Guide to the Principal Gold and Silver Coins of the Ancients: From Circa B.C. 700 to A.D.1. Chicago 1968.

J. Heinrichs, "Military Integration in Late Archaic Arcadia: New Evidence From A Bronze Pinax (ca.500 B.C) of the Lykaion". Eds. W. Heckel, S. Müller - G. Wrightson, The Many Faces of War in the Ancient World. UK (2015) 1-90.

O. Henry, A. G. Bilgin-Altınöz, J. Blid, Ö. D. Çakmaklı, A. Dufton, A. Freccero, L. Gosner, R. Hedlund, P. Lebouteiller, V. Lungu, F. Rojas, F. Tobin, B. Vergnaud - A. Waters, "La Mission Labraunda 2013- Rapport Preliminaire". Anatolia Antiqua 12 (2014) 255-325.

L. L. Holland, "Marriage, Sacred, Greece and Rome". 2012. Accessed from: https://doi.org/10.1002/9781444338386.wbeah17257 (published online 07.02.2012)

S. Hornblower, Mausolus. Oxford 1982.

N. F. Jones, Public Organization in Ancient Greece: A Documentary Study. Philadelphia 1987.

L. Karlsson, "Labraunda 2007". Kazı Sonuçları Toplantısı 30/1 (2008) 107118.

A. Kızıl, P. Brun, L. Capdetrey, R. Descat, P. Fröhlich - K. Konuk, "Pidasa et Asandros: Une Nouvelle Inscription (321/0)". REA 117/2 (2015) 371-409.

K. Konuk, "The Coinage of Hyssaldomos, Dynast of Mylasa". Eds. R. Einicke, S. Lehmann, H. Löhr, G. Mehnert, A. Mehnert - A. Slawish, Zurück Zum Gegenstand Festschrift Für Andreas E. Furtwangler Band II, Langenweißbach (2009) 357-365.

K. Konuk, "Hekatomnoslar Hanedanı". Antik Anadolu'nun Tanıkları: Muharrem Kayhan Koleksiyonu. İzmir 2015.

S. N. Kramer, The Sacred Marriage Rite: Aspects of Faith, Myth and Ritual in Ancient Sumer. Bloomington 1958.

C. C. Küçükeren, Ege'de Bir Anadolu Uygarlığı: Karya (Karuwa/ Karka/ Karkişa/ Krk). İstanbul $2007^{2}$.

J. LaBuff, "Who(')s(e) Karian? Language, Names and Identity". Ancient History Bulletin 27/3-4 (2013) 86-108.

H. G. Liddell - R. Scott, A Greek-English Lexicon, Machine Readable Text. Oxford 1940. Accessed from: http://perseus.uchicago.edu

A. Maiuri, "Viaggio di esplorazione in Caria. II". ASAA (1921-1922) 405-419.

M. Meier-Brügger, "Karika II-III". Kadmos 18 (1979) 80-88.

H. C. Melchert, Historical Phonology of Anatolian. Journal of IndoEuropean Studies 21/3-4 (1993) 237-257. 
Meyer 1925

Migeotte - Kontorini 1995

Moore 2013

Nilsson 1909

Newton 1881

O’Brien 2007

Oğuz-Kırca 2014a

Oğuz-Kırca 2014b

Oğuz-Kırca 2015

Oğuz-Kırca 2016

Oğuz-Kırca 2017

Öniz 2010

Özdoğan 2006

Papachristodoulou 1999

Paton - Myres 1896

Pedersen 1994

Peschlow-Bindoka 2003

Radt 1970

Ratté 2005

Rice 1999

Robert - Robert 1955

Ruggieri 2009

Saner - Kuban 1999

Santini 2017

Sherk 1990
E. Meyer, Die Grenzen Der Hellenistischen Staaten in Kleinasien. Zürich 1925.

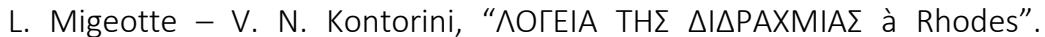
Bulletin de Correspondance Hellénique 119 (2) (1995) 621-628.

D. Moore, Dawn of Discovery: The Early British Travellers to Crete. UK 2013.

M. P. Nilsson, Timbres Amphoriques de Lindos: Publiés Avec Une Étude Sur Les Timbres Amphoriques Rhodien. Copenhague 1909.

C. T. Newton, "On An Unedited Rhodian Inscription". The Journal of Hellenic Studies 2 (1881) 354-361.

P. K. O'Brien, Atlas of the World History: From the Origins of Humanity to the Year 2000. USA 2007.

E. D. Oğuz-Kırca, "Some Thoughts on the Problem of Identification of Demes: The Ancient Bozburun Peninsula". Cedrus 2 (2014) 267-289.

E. D. Oğuz-Kırca, "On the Location and Territorium of Hygassos". Höyük 7 (2014) 33-43.

E. D. Oğuz-Kırca, "The Chora and The Core: A General Look At the Rural Settlement Pattern of (Pre) Hellenistic Bozburun Peninsula, Turkey". PAUSBED 20 (2015) 33-62.

E. D. Oğuz-Kırca, "Tymnos'un Kayıp Mabedi: Hera ve Zeus'a Adanan Tapınak Neredeydi? (The Lost Sanctuary of Tymnos: Where Was the Naiskos Dedicated to Hera and Zeus?)". Arkeoloji ve Sanat Dergisi (Journal of Archaeology and Art) 151 (2016) 231-247.

E. D. Oğuz-Kırca, "Three Amphora Stamps From Tymnos (Bozburun, Turkey): A Case Study Regarding Provenance". Scientific Culture 3/3 (2017) 31-43.

A. Öniz, "Urania: Bir Leleg Yerleşimi". Aktüel Arkeoloji Dergisi 13 (2010) 54-56.

M. Özdoğan, "Sır Taşlar". Arkeoatlas 5 (2006) 140-146.

I. Papachristodoulou, "The Rhodian Demes Within the Framework of the Function of the Rhodian State". Eds. V. Gabrielsen, P. Bilde, T. EngbergPedersen, L. Hannestad - J. Zahle, Hellenistic Rhodes: Politics, Culture, and Society, Studies in Hellenistic Civilization (vol. 9). Aarhus (1999) 27-44.

W. R. Paton - J. L. Myres, "Karian Sites and Inscriptions". The Journal of Hellenic Studies 16 (1896) 188-271.

P. Pedersen, "The Fortifications of Halikarnassos". Revue des Études Anciennes 96/ 1-2 (1994) 215-235.

A. Peschlow-Bindokat, Frühe Menschenbilder: Die Prähistorischen Felsmalereien des Latmos-Gebirges (West Türkei). Mainz am Rhein 2003.

W. Radt, Siedlungen und Bauten auf der Halbinsel von Halikarnassos unter besonderer Berücksichtigung der archaischen Epoche. Istanbuler Mitteilungen Beiheft 3. Tübingen 1970.

C. Ratté, "The Carians and the Lydians". Ed. F. Rumscheid, Die Karer und die Anderen. Bonn (2005) 135-149.

E. E. Rice, "Relations Between Rhodes and the Rhodian Peraea". Eds. V. Gabrielsen, P. Bilde, T. Engberg-Pedersen, L. Hannestad - J. Zahle, Hellenistic Rhodes: Politics, Culture, and Society. Aarhus (1999) 45-53.

L. Robert - J. Robert. ----- Bulletin Épigraphique 68 (1955) 206-219.

V. Ruggieri, "The Carians in the Byzantine Period". Ed. F. Rumscheid, Die Karer und die Anderen. Bonn (2009) 207-218.

T. Saner - Z.Kuban, "Kıran Gölü 1998". Kazı Sonuçları Toplantısı 17/2 (1999) 287-295.

M. Santini, "Bellerephontes, Pegasos and the Foundation of Halikarnassos. Contributions to the Study of the Salmakis Inscription". Studi Classici e Orientali 63 (2017) 109-143. DOI: 10.12871/97888674179199

R. K. Sherk, "The Eponymous Officials of Greek Cities: Mainland Greece and the Adjacent Islands". Zeitschrift für Papyrologie und Epigraphik 84 (1990) 231-295.

Sina 2003
A. Sina, Karya Panamara'da Bulunan Saç Adakları Yazıtları. Tarih Araştırmaları Dergisi 22/34 (2003) 125-134. 
Sivrioğlu 2017

Schliemann 2014

Sokolowski 1956

Souyoudzoglou-Haywood 1999

Spratt 1865

Spratt 1886

Şahin 2001

Talbert 2000

Taşdöner 2008

Taşlıgil 2008

Taşlıklıoğlu 1963

Thomsen 2015

Umar 1993

Umar 1999

Uyguç 1992

van Bremen 2007

van Straten 1995

Varinlioğlu et al. 1992

Vollgraf 1934

Williamson 2009

Williamson 2016
U. T. Sivrioğlu, “Erken Hıristiyan Literatürü’nde Yahudiler ve Anti-Semitizm (Jews and Anti-Semitism in Early Christian Literature". Seleucia VII (Olba Kazısı Serisi) (2017) 235-279.

H. Schliemann, Troya'dan Ida Dağı'na Troas'ta Yolculuk (Reise in der Troas im Mai 1881). Trans: I. PInar. Istanbul 2014.

F. Sokolowski, "On the Lex Sacra of Tymnos". Transactions and Proceedings of the American Philological Association 87 (1956) 47-50.

C. Souyoudzoglou-Haywood, The Ionian Islands in the Bronze Age and Early Iron Age 3000-800 B.C. Liverpool 1999.

T. A. B, Spratt, Travels and Researches in Crete, Vol. I. London 1865.

T. A. B, Spratt, "Remarks on the Dorian Peninsula and Gulf, with Notes on a Temple of Latona There". Archaeologia 49.2 (1886) 345-365.

N. Şahin, Zeus'un Anadolu Kültleri. İstanbul 2001.

R. J. A. Talbert, Barrington Atlas of the Greek and Roman World: Map-ByMap Directory (Vol II). Princeton - Oxford 2000.

K. Taşdöner, Karya Kenti Halikarnassos. Adıyaman Üniversitesi Sosyal Bilimler Enstitüsü Dergisi 1 (2008) 96-106.

N. Taşlıgil, "Datça- Bozburun Özel Çevre Koruma Bölgesi ve Turizm (Tourism and Special Environmental Protected Areas: Case of DatçaBozburun)". Ege Coğrafya Dergisi 17/1-2 (2008) 73-83.

Z. Taşlıklıoğlu, Anadolu'da Apollon Kültü ile Ilgili Kaynaklar. İstanbul 1963.

C. A. Thomsen, "The Eranistoi of Classical Athens". Greek, Roman, and Byzantine Studies 55 (2015) 154-175.

B. Umar, Türkiye'deki Tarihsel Adlar: Türkiye'nin Tarihsel Coğrafyası ve Tarihsel Adları Üzerine Alfabetik Düzende Bir Inceleme. İstanbul 1993.

B. Umar, Karia: Bir Tarihsel Coğrafya Araştırması ve Gezi Rehberi. İstanbul 1999.

A. Uyguç, Güneybatı Anadolu'nun Tarih Öncesi Halkı: Kar'lar. Çine 1992.

R. van Bremen, "Networks of Rhodians in Karia". Mediterranean Historical Review 22/1 (2007) 113-132.

F. T. van Straten, Hiera Kala: Images of Animal Sacrifice in Archaic and Classical Greece. Leiden - New York - Köln 1995.

E. Varinlioğlu, A. Bresson,P. Brun, P. Debord - R. Descat, "Ouranion en Carie". Revue des Études Anciennes 94/1-2 (1992) 155-174.

W. Vollgraf, "Une Offrande a Enyalios". Bulletin de Correspondance Hellénique 58 (1934) 138-156.

C. G. Williamson, "Panamara: The (mis)fortunes of a Karian Sanctuary". Groniek 42/183 (2009) 211-218.

C. G. Williamson, "A Carian Shrine in a Hellenising World". Eds. M.-P. de Hoz, J. P. Sanchez Hernández - C. M.Valero, Between Tarhuntas and Zeus Polieus: Cultural Crossroads in the Temples and Cults of Graeco-Roman Anatolia. Leuven - Paris - Bristol (2016) 75-101.

\section{Online Sources}

http://enacademic.com (Academic Dictionaries and Encyclopedias)

http://www.perseus.tufts.edu

https://theodora.com/encyclopedia/l/leleges.html.

https://www.worldwildlife.org/ecoregions/pa1201 (World Wildlife Fund, Southeastern Europe: Along the Coastline of Greece and Turkey, Stretching into Macedonia. Scientific Code: PA 1201)

http://ockb.csb.gov.tr/datca-bozburun-ozel-cevre-koruma-bolgesi-i-2747

Searchable Greek Inscriptions. A Scholarly Tool in Progress (The Packard Humanities Institute- Project Centers/ Attica (IG (I-III) IG I3; Aegean Islands, incl. Crete (IG XI-[XIII]); Asia Minor: Caria, Rhodian Peraia: IK Rhodische Peraia, McCabe, Rhodian Peraia; Caria: McCabe, Iasos; Cilicia and Isauria: IK Anazarbos, I; Ionia: Milet VI,3; Caria: McCabe,Mylasa; Lycia: Petersen and Luschan, Reisen im südwestlichen Kleinasien II; Lycia: Petzl, in: Freyer-Schauenburg, Lykische Zwölfgötter-Reliefs; SEG (Supplementum Epigraphicum Graecum) (30.03.2018). Accessed from: http://epigraphy.packhum.org /inscriptions/main 